\title{
Summary of Non-U.S. National and International Radioactive Waste Mangement Programs
} 1980

\author{
K. M. Harmon \\ J. A. Kelman \\ L. A. Stout \\ K. A. Hsieh
}

March 1980

Prepared for the U.S. Department of Energy under Contract EY-76-C-06-1830

Pacific Northwest Laboratory Operated for the U.S. Department of Energy by Battelle Memorial Institute 
This report was prepared as an account of work sponsored by the United States Government. Neither the United States nor the Department of Energy, nor any of their employees, nor any of their contractors, subcontractors, or their employees, makes any warranty, express or implied, or assumes any legal liability or responsibility for the accuracy, completeness or usefulness of any information, apparatus, product or process disclosed, or represents that its use would not infringe privately owned rights.

The views, opinions and conclusions contained in this report are those of the contractor and do not necessarily represent those of the United States Government or the United States Department of Energy.

\author{
PACIFIC NORTHWEST LABORATORY \\ operated by \\ BATTELLE \\ for the \\ UNITED STATES DEPARTMENT OF ENERGY \\ Under Contract EY-76-C-06-1830
}
Printed in the United States of America
Available from
National Technical Information Service
United States Department of Commerce
5285 Port Royal Road
Springfield, Virginia 22151

Price: Printed Copy $\$$ : Microfiche $\$ 3.00$

$\begin{array}{cc}\text { •Pages } & \begin{array}{c}\text { Selling Price } \\ \end{array} \\ 001-025 & \$ 4.00 \\ 026-050 & \$ 4.50 \\ 051-075 & \$ 5.25 \\ 076-100 & \$ 6.00 \\ 101-125 & \$ 6.50 \\ 126-150 & \$ 7.25 \\ 151-175 & \$ 8.00 \\ 176-200 & \$ 9.00 \\ 201-225 & \$ 9.25 \\ 226-250 & \$ 9.50 \\ 251-275 & \$ 10.75 \\ 276-300 & \$ 11.00\end{array}$


PNL -3333

UC-70

\section{7}

SUMMARY OF NON-U.S. NATIONAL AND INTERNATIONAL RADIOACT IVE

WASTE MANAGEMENT PROGRAMS

1980

K. M. Harmon

J. A. Kelman

L. A. Stout

K. A. Hsieh

March 1980

Prepared for

the U.S. Department of Energy under Contract EY-76-C-06-1830

Pacific Northwest Laboratory Richland, Washington 99352 
. 


\section{CONTENTS}

ACRONYMNS, ABBREVIATIONS AND SYMBOLS . . . . . . . . . . . . . v v

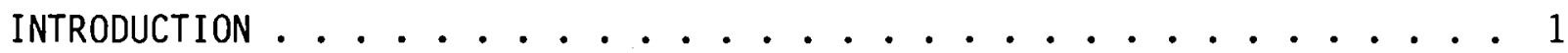
NUCLEAR FUEL CYCLE AND WASTE MANAGEMENT ACTIVITIES . . . . . . . . . . 2 NATIONAL AND INTERNATIONAL PROGRAM OVERVIEWS . . . . . . . . . . 17

ARGENTINA . . . . . . . . . . . . . . . . . . . 17 NUCLEAR FUEL CYCLE POLICY AND PROGRAMS . . . . . . . . . . . 17 ORGANIZATION . . . . . . . . . . . . . . . . . . . 18 COMMERCIAL NUCLEAR ACTIVITIES . . . . . . . . . . . . . 18 FUEL CYCLE AND WASTE TREATMENT R\&D . . . . . . . . . . . . . . . 18

AUSTRALIA . . . . . . . . . . . . . . . . . . . 18 NUCLEAR FUEL CYCLE POLICY AND PROGRAMS . . . . . . . . . . . . . . . 18

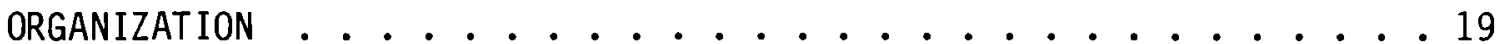
COMMERCIAL NUCLEAR ACTIVITIES . . . . . . . . . . . . . . . . 20 FUEL CYCLE AND WASTE MANAGEMENT R\&D . . . . . . . . . . . . 20

AUSTRIA . . . . . . . . . . . . . . . . . . 22 NUCLEAR FUEL CYCLE POLICY AND PROGRAMS . . . . . . . . . . . . 22 SELECTED AGENCIES AND NUCLEAR RESEARCH CENTERS . . . . . . . . . 22 COMMERCIAL NUCLEAR ACTIVITIES . . . . . . . . . . . . . . 23 WASTE TREATMENT R\&D . . . . . . . . . . . . . . . . 23 WASTE DISPOSAL ..................... 23

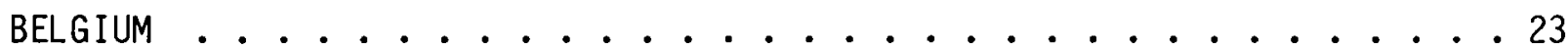
NUCLEAR FUEL CYCLE POLICY AND PROGRAMS . . . . . . . . . . 23 ORGANIZATION . . . . . . . . . . . . . . . . . 24 COMMERCIAL NUCLEAR ACTIVITIES . . . . . . . . . . . . . . . . 25 FUEL CYCLE AND WASTE MANAGEMENT R\&D .................. 26 WASTE DISPOSAL ...................... 26

BRAZIL . . . . . . . . . . . . . . . . . . . . 27 NUCLEAR FUEL CYCLE POLICY AND PROGRAMS . . . . . . . . . . 27 ORGANIZATION . . . . . . . . . . . . . . . . . . . . 28 COMMERCIAL NUCLEAR ACTIVITIES . . . . . . . . . . . . . . 28 FUEL CYCLE AND WASTE MANAGEMENT R\&D . . . . . . . . . . . . . 28

CANADA . . . . . . . . . . . . . . . . . . . . . . 9 NUCLEAR FUEL CYCLE POLICY AND PLANS .

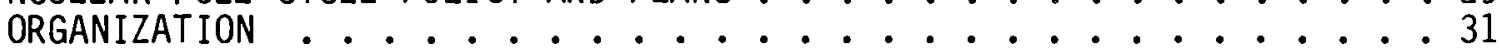
COMMERCIAL NUCLEAR ACTIVITIES . . . . . . . . . . . . . . 32 FUEL CYCLE AND WASTE MANAGEMENT R\&D ............... 32 
DENMARK .. . . . . . . . . . . . . . . . . . . . . . 34

NUCLEAR FUEL CYCLE POLICY AND PROGRAMS

ORGANIZATION ......................... 35

WASTE MANAGEMENT . . . . . . . . . . . . . . . . . 35

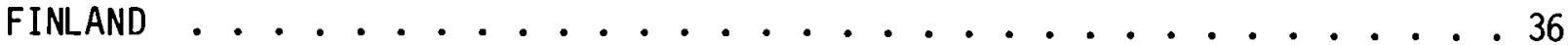

NUCLEAR FUEL CYCLE POLICY AND PROGRAMS . . . . . . . . . . . . 36

SELECTED RESEARCH CENTERS . . . . . . . ......... 36

COMMERCIAL NUCLEAR ACTIVITIES . . . . . . . . . . . . . 37

WASTE TREATMENT R\&D . . . . . . . . . . . . . . . . 37

WASTE DISPOSAL ..................... 37

FRANCE . • • • • • . . . . . . . . . . . . . . . . . . 37

NUCLEAR FUEL CYCLE POLICY AND PROGRAMS . . . . . . . . . . . . 37

ORGANIZATION . . . . . . . . . . . . . . . . . . . . 38

COMMERCIAL NUCLEAR ACTIVITIES . . . . . . . . . . . . . . . . . . . 39

FUEL CYCLE AND WASTE MANAGEMENT R\&D . . . . . . . . . . . . . . . . 41

FEDERAL REPUBLIC OF GERMANY . . . . . . . . . . ....... 43

NUCLEAR FUEL CYCLE POLICY AND PROGRAMS ............... 43

ORGANIZATION . . . . . . . . . . . . . . . . . . . 43

COMMERCIAL NUCLEAR ACTIVITIES . . . . . . . . . . . . . 45

FUEL CYCLE AND WASTE MANAGEMENT R\&D . . . . . . . . . . . . 46

INDIA . . . . . . . . . . . . . . . . . . . 4 49

NUCLEAR FUEL CYCLE POLICY AND PROGRAMS . . . . . . . . . . . . 49

SELECTED AGENCIES AND NUCLEAR CENTERS ............... 49

COMMERCIAL NUCLEAR ACTIVITIES . . . . . . . . . . . . . . . 49

WASTE TREATMENT R\&D . . . . . . . . . . . . . . . . . . 50

WASTE DISPOSAL . . . . . . . . . . . . . . . . . 50

ITALY . . . . . . . . . . . . . . . . . . 50

NUCLEAR FUEL CYCLE POLICY AND PROGRAMS .

ORGANIZATION . . . . . . . . . . . . . . . . . . . 51

COMMERCIAL NUCLEAR ACTIVITIES . . . . . . . . . . . . . 51

FUEL CYCLE AND WASTE TREATMENT R\&D . . . . . . . . . . . . . 52

WASTE DISPOSAL ....................... 53

JAPAN . . . . . . . . . . . . . . ......... 53

NUCLEAR FUEL CYCLE POLICY AND PROGRAMS . . . . . . . . . . . . . 53

ORGANIZATION . . . . . . . . . . . . . . . . . . . . 54

COMMERCIAL NUCLEAR ACTIVITIES . . . . . . . . . . . . . . 55

FUEL CYCLE AND WASTE MANAGEMENT R\&D................ . 56

D\&D . . . . . . . . . . . . . . . . . . . . . 58

WASTE DISPOSAL ....................... 58 
MEXICO . . • . . . . . . . . . . . . . . . . . . . 58

NUCLEAR FUEL CYCLE POL ICY AND PROGRAMS

SELECTED AGENCIES AND RESEARCH CENTERS . . . . . . . . . . . . 59

COMMERCIAL NUCLEAR ACTIVITIES . . . . . . . . . . . . . . 59

FUEL CYCLE R\&D ........................ 59

NETHERLANDS . . . . . . . . . . . . . . . . . . . . . . . 59

NUCLEAR FUEL CYCLE POLICY AND PROGRAMS . . . . . . . . . . . 59

ORGANIZATION ....................... . . . 60

COMMERCIAL NUCLEAR ACTIVITIES . . . . . . . . . . . . . 60

FAST BREEDER REACTOR . . . . . . . . . . . . . . . 60

FUEL CYCLE AND WASTE MANAGEMENT R\&D................. 61

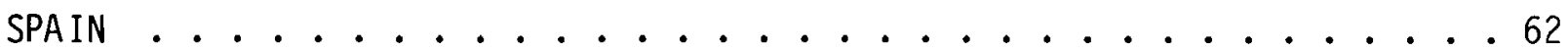

NUCLEAR FUEL CYCLE POLICY AND PROGRAMS . . . . . . . . . . . 62

SELECTED AGENCIES AND RESEARCH CENTERS . . . . . . . . . . . 62

COMMERCIAL NUCLEAR ACTIVITIES .................. 63

FUEL CYCLE AND WASTE TREATMENT R\&D . . . . . . . . . . . . . . 63

WASTE ISOLATIONS .................... 63

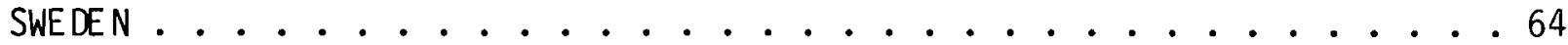

NUCLEAR FUEL CYCLE POLICY AND PROGRAMS . . . . . . . . . . 64

ORGANIZATION . . . . . . . . . . . . . . . . . . . . 66

COMMERCIAL NUCLEAR ACTIVITIES . . . . . . . . . . . . . 66

WASTE MANAGEMENT R\&D . . . . . . . . . . . . . . . . . 66

WASTE DISPOSAL ....................... 67

R\&D . . . . . . . . . . . . . . . . . . . 69

SWITZERLAND . . . . . . . . . . . . . . . . . . . . . 69

NUCLEAR FUEL CYCLE POLICY AND PROGRAMS . . . . . . . . . . . . . 69

SELECTED AGENCIES AND RESEARCH CENTERS . . . . . . . . . . . . 69

COMMERCIAL NUCLEAR ACTIVITIES . . . . . . . . . . . . . . 70

WASTE DISPOSAL . . . . . . . . . . . . . . . . . 70

UNITED KINGDOM . . . . . . . . . . . . . . . . . . . . 70

NUCLEAR FUEL CYCLE POLICY AND PROGRAMS . . . . . . . . . . . 70

ORGANIZATION . . . . . . . . . . . . . . . . . . . . . 72

COMMERCIAL NUCLEAR ACTIVITIES . . . . . . . . . . . . . . . . 73

FUEL CYCLE AND WASTE TREATMENT R\&D . . . . . . . . . . . . . . 74

WASTE DISPOSAL . . . . . . . . . . . . . . . 76

R\&D............................. 77

UNION OF SOVIET SOCIALIST REPUBLICS . . . . . . . . . . . . . . . . 77

NUCLEAR FUEL CYCLE POLICY AND PROGRAMS . . . . . . . . . . . 77

ORGANIZATION . . . . . . . . . . . . . . . . . . . . 78

COMMERCIAL NUCLEAR ACTIVITIES . . . . . . . . . . . . . . 78

FUEL CYCLE AND WASTE MANAGEMENT R\&D . . . . . . . . . . . . 78

WASTE DISPOSAL ....................... 79 
INTERNATIONAL ATOMIC ENERGY ASSOCIATION (IAEA) . . . . . . . 80

COMMISS ION OF EUROPEAN COMMUNITIES (CEC) . . . . . . . . 82

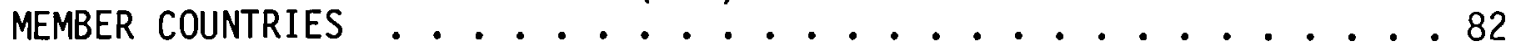

JOINT RESEARCH CENTRE-ISPRA $\ldots . . . . . . . .83$

EUROPEAN TRANSURANIUM INSTITUTE .............. 84

NUCLEAR ENERGY AGENCY (NEA) (ORGANIZATION FOR ECONOMIC COOPERATION

AND DEVELOPMENT) .................... . . . 84

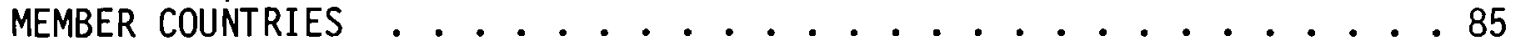

EUROCHEMIC (EUROPEAN COMPANY FOR THE CHEMICAL PROCESSING OF

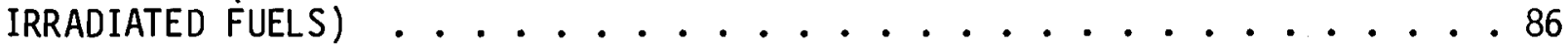

COUNCIL FOR MUTUAL ECONOMIC ASSISTANCE (CMEA) . . . . . . . 87

MEMBER COUNTRIES ..................... . . . 87

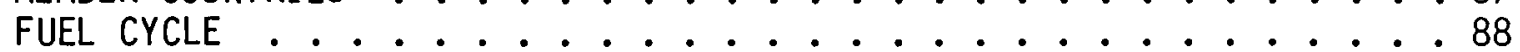

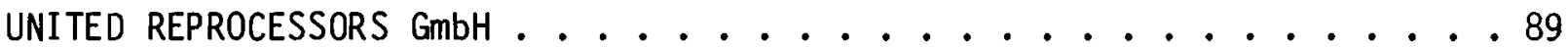

NUCLEAR TRANSPORT LIMITED $(\mathrm{NTL}) \ldots . \ldots . \ldots . \ldots$ 


\section{TABLES}

1. Industrial Nuclear Power Production ............. 3

2. Industrial Fuel Cycle Activities ............. 6

3. Spent Fuel Arisings Through December $1979 \ldots . . . . . . .7$

4. Waste Management Activities . . . . . . . . . . . . 8

5. Membership in International Agencies ............ 9

6. Nuclear Waste Management Highlights, March 1979 -- March 1980 . . . 11 
ACRONYMNS, * ABBREVIATIONS AND SYMBOLS

AFR

AVM

BWR

CANDU

FBR

FINGAL/HARVEST

FIPS

FRP

GCR

GWe

HFR

HLLW

HLW

HTG R

HTR

HWLWR

HWR

LGR

LLW

LMFBR

LOTES

LWCHW

LWR

MOX
Away-from-reactor

Waste vitrification plant at Marcoule, France

Boiling water reactor

Canadian deuterium uranium reactor

Fast breeder reactor

British waste vitrification process

West German process for vitrifying high-level waste, developed at Julich

Fuel reprocessing $p$ lant

Gas-cooled reactor

$10^{9}$ watts of electricity $1000 \mathrm{MWe}$

High Flux Reactor at Petten, Netherlands

High-level liquid waste

High-level waste

High-temperature gas-cooled reactor

High-temperature reactor

Heavy water moderated, light water cooled reactor (same as LWCHW)

Heavy water reactor

Light water cooled, graphite moderated reactor

Low-level waste

Liquid metal fast breeder reactor

Low-temperature solidification (waste calcination) process developed by Eurochemic

Light water cooled, heavy water moderated reactor (s ame as HWLWR)

Light water reactor

Mixed (plutonium-uranium) oxide

*Acronyms for agencies, institutes, etc. are given in the Overview section for each country. 
tHM

MTR

tU

tSWU

PAMELA

PFR

PHWR

PIVER

$R \& D$

THTR

TRU

VERA

WAK
Metric tons (tonnes) heavy metal

Materials test reactor

Metric tons uranium

Metric tons of separative work (uranium enrichment)

West German and Eurochemic process for converting $\mathrm{h}$ igh-level waste to glass beads and embedding them in a metal alloy

Prototype Fast Reactor (UK)

Pressurized heavy water reactor

Pilot Verres, French HLLW vitrification process

Research and development

Thor ium high-temperature reactor

Transuranic

West Germany process for vitrifying high-level waste, developed at Karlsruhe

Fuel reprocessing pilot plant near Karlsruhe 
SUMMARY OF NON-U.S. NATIONAL AND INTERNATIONAL

RADIOACTIVE WASTE MANAGEMENT PROGRAMS

1980

\section{INTRODUCTION}

Many nations and international agencies are working to develop improved technology and industrial capability for nuclear fuel cycle and waste management operations. The effort in some countries is limited to research in university laboratories on treating low-level waste from reactor plant operations. In other countries, national nuclear research institutes are engaged in major programs in all phases of the fuel cycle and waste management, and there is a national effort to commercialize fuel cycle operations.

Since late 1976, staff members of Pacific Northwest Laboratory have been working under U.S. Department of Energy sponsorship to assemble and consolidate openly available information on foreign and international nuclear waste management programs and technology. This report summarizes the information collected on the status of fuel cycle and waste management programs in selected countries making major efforts in these fields as of the end of January 1980. 


\section{NUCLEAR FUEL CYCLE AND WASTE MANAGEMENT ACT IVITIES}

Six tables are included in this section:

Table 1, Industrial Nuclear Power Production, lists the nations operating, building or planning to build nuclear power stations and provides the latest data available concerning present commitments ( $\mathrm{plants}$ built, under construction or on order) and long-term projections.

Table 2, Industrial Fuel Cycle Activities, lists the nations which are operating or planning to construct major fuel cycle facilities.

Table 3, Spent Fuel Arisings Through December 1979, shows Cumulated GWD and other spent fuel data.

Table 4, Waste Management R\&D Activities, 1 ists the nations and international agencies which have active programs for waste treatment and waste isolation -- either R\&D or commercial-scale.

Table 5, Membership in International Agencies, 1 ists nations and their affiliations with international agencies directly concerned with the nuclear fuel cycle and waste management activities.

Table 6, Nuclear Waste Management Highlights, March 1979 -- March 1980, covers events in 1979 which had major significance in the field of waste management. 
TABLE 1. Industrial Nuclear Power Production

\begin{tabular}{|c|c|c|c|c|c|}
\hline \multirow{2}{*}{$\frac{\text { Country }}{\text { Argentina }}$} & \multicolumn{3}{|c|}{ Committed (GWe)(a) } & \multicolumn{2}{|c|}{ Projected (GWe) } \\
\hline & PHWR: & $\begin{array}{l}0.93 \\
1.63\end{array}$ & $\begin{array}{l}(1981) \\
\text { (1ate 1980's) }\end{array}$ & 4.0 & $(2000)$ \\
\hline Australia & & & & 1.0 & $(2000)$ \\
\hline Austria(b) & LWR: & 0.69 & $(1980)$ & & \\
\hline Belgium & LWR: & $\begin{array}{l}1.65 \\
5.5\end{array}$ & $\begin{array}{l}(1980) \\
(1985)\end{array}$ & & \\
\hline Brazil & LWR: & $\begin{array}{l}0.63 \\
3.1\end{array}$ & $\begin{array}{l}(1980) \\
(1987)\end{array}$ & 60 & $(2000)-45 \%$ \\
\hline Butgaria & LWR: & 1.76 & (1980) & 5.8 & $(1995)-40 \%$ \\
\hline Canada & $\begin{array}{l}\text { BLWR: } \\
\text { PHWR: }\end{array}$ & $\begin{array}{l}0.25 \\
4.5 \\
15\end{array}$ & $\begin{array}{l}(1980) \\
(1980) \\
(1990)\end{array}$ & 45 & $(2000)$ \\
\hline Chile & & & & 0.6 & (1988) \\
\hline Cuba & LWR: & 0.44 & (1985) & 1.76 & (1990) \\
\hline Czechos lovakia & $\begin{array}{l}\text { GCHWR: } \\
\text { LWR: }\end{array}$ & $\begin{array}{l}0.11 \\
0.88 \\
3.5\end{array}$ & $\begin{array}{l}(1980) \\
(1980) \\
(1984)\end{array}$ & 10.3 & (1990) \\
\hline $\begin{array}{l}\text { Democratic } \\
\text { Repubtic of } \\
\text { Germany }\end{array}$ & LWR: & $\begin{array}{l}1.76 \\
2.7\end{array}$ & $\begin{array}{l}(1980) \\
(\text { ear ly 1980's) }-99\end{array}$ & $9 \%$ & $(1990)-15 \%$ \\
\hline Egypt & LWR: & 0.6 & $(1987)$ & 6.6 & (2000) \\
\hline $\begin{array}{l}\text { Federal } \\
\text { Republic of } \\
\text { Germany }\end{array}$ & $\begin{array}{l}\text { PHWR: } \\
\text { LMFBR: } \\
\text { THTR: } \\
\text { LWR: }\end{array}$ & $\begin{array}{c}0.05 \\
0.30 \\
0.30 \\
8.8 \\
19.6 \\
25.9\end{array}$ & $\begin{array}{l}(1980) \\
(1985) \\
(1982) \\
(1980)-13 \% \\
(1985) \\
\text { (Indef.) }\end{array}$ & 53 & $(2000)$ \\
\hline Fintand & LWR: & 2.16 & $(1980)-35 \%$ & & \\
\hline France & $\begin{array}{l}\text { GCR: } \\
\text { GCHWR: } \\
\text { LMFBR: } \\
\text { LWR: }\end{array}$ & $\begin{array}{l}2.2 \\
0.07 \\
0.23 \\
1.43 \\
10.9 \\
41.8\end{array}$ & $\begin{array}{l}(1980) \\
(1980) \\
(1980) \\
(1983) \\
(1980) \\
(1986)\end{array}$ & LMFBR: 25 & $(2000)$ \\
\hline
\end{tabular}




\begin{tabular}{|c|c|c|c|c|c|}
\hline Country & \multicolumn{3}{|c|}{ Committed (GWe) (a) } & \multicolumn{2}{|c|}{ Projected (GWe) } \\
\hline Greece & & & & 0.6 & (1988) \\
\hline Hungary & LWR: & 1.76 & $(1985)$ & & \\
\hline India & $\begin{array}{l}\text { LWR: } \\
\text { PHWR: }\end{array}$ & $\begin{array}{l}0.40 \\
0.62 \\
1.28\end{array}$ & $\begin{array}{l}(1980) \\
(1980) \\
(1984)\end{array}$ & 6 & $(1990)-7 \%$ \\
\hline Iraq & LWR: & 0.9 & (?) & & \\
\hline Israe 1 & & & & 1.8 & (1990) \\
\hline Italy & $\begin{array}{l}\text { GCR: } \\
\text { LWCHW: } \\
\text { LWR: }\end{array}$ & $\begin{array}{l}0.15 \\
0.04 \\
1.24 \\
3.2 \\
5.1\end{array}$ & $\begin{array}{l}(1980) \\
(1983) \\
(1980) \\
\text { (1985) } \\
\text { (Indef.) }\end{array}$ & 12 & $(2000)$ \\
\hline Japan & $\begin{array}{l}\text { GCR: } \\
\text { LWCHW: } \\
\text { LMFBR: } \\
\text { LWR: }\end{array}$ & $\begin{array}{c}0.16 \\
0.20 \\
0.30 \\
14.2 \\
19.8\end{array}$ & $\begin{array}{l}(1980) \\
(1980) \\
(1985) \\
(1980) \\
(1985)\end{array}$ & 80 & (1996) \\
\hline Korea (South) & $\begin{array}{l}\text { PHWR: } \\
\text { LWR: }\end{array}$ & $\begin{array}{l}0.63 \\
0.56 \\
4.9\end{array}$ & $\begin{array}{l}(1982) \\
(1980) \\
(1987)\end{array}$ & 10 & (1991) \\
\hline Kuwa it & & & & 3.6 & $(2000)-30 \%$ \\
\hline Libya & LWR: & 0.30 & (Indef.) & & \\
\hline Luxembourg & LWR: & 1.25 & (Indef.) & & \\
\hline Mexico & LWR: & 1.31 & $(1983)$ & 6.7 & (1999) \\
\hline Nether lands & LWR: & 0.49 & $(1980)$ & & \\
\hline Pakistan & PHWR: & 0.12 & $(1980)$ & 16 & $(2000)-60 \%$ \\
\hline Philippines & LWR: & 1.24 & (1982) & & \\
\hline Pol and & LWR: & 0.88 & (1986) & 23 & $(2000)-25 \%$ \\
\hline Romania & LWR: & $\begin{array}{l}0.44 \\
1.04\end{array}$ & $\begin{array}{l}\text { (1983) } \\
\text { (Indef.) }\end{array}$ & 4 & $(1990)-18 \%$ \\
\hline South Africa & LWR: & 1.84 & (1984) & & \\
\hline
\end{tabular}




\begin{tabular}{|c|c|c|c|c|c|}
\hline Country & \multicolumn{3}{|c|}{ Committed (GWe) (a) } & \multicolumn{2}{|c|}{ Projected (GWe) } \\
\hline Spain & $\begin{array}{l}\text { GCR: } \\
\text { LWR: }\end{array}$ & $\begin{array}{l}0.48 \\
1.52 \\
10.9 \\
12.8\end{array}$ & $\begin{array}{l}(1980) \\
1980) \\
(1987) \\
\text { (Indef.) }\end{array}$ & & \\
\hline Sweden & LWR: & $\begin{array}{l}7.3 \\
9.4\end{array}$ & $\begin{array}{l}(1980) \\
(1985)\end{array}$ & & \\
\hline Switzer land & LWR: & $\begin{array}{l}1.94 \\
3.8 \\
4.9\end{array}$ & $\begin{array}{l}(1980) \\
\text { (1987) } \\
\text { (Indef.) }\end{array}$ & & \\
\hline Taiwan & LWR: & $\begin{array}{l}1.20 \\
4.9\end{array}$ & $\begin{array}{l}(1980) \\
1985)\end{array}$ & & \\
\hline Turkey & LWR: & 0.44 & (Indef.) & 5 & (1990) \\
\hline United Kingdom & $\begin{array}{l}\text { HWLWR: } \\
\text { LMFBR: } \\
\text { GCR \& AGR: }\end{array}$ & $\begin{array}{c}0.09 \\
0.25 \\
8.3 \\
11.4\end{array}$ & $\begin{array}{l}(1980) \\
(1980) \\
(1980) \\
(1982)\end{array}$ & $25-40$ & $(2000)$ \\
\hline USA & $\begin{array}{l}\text { LWBR: } \\
\text { HTGR: } \\
\text { LGR: } \\
\text { LWR: }\end{array}$ & $\begin{array}{c}0.06 \\
0.33 \\
0.86 \\
62.2 \\
140.8 \\
177.0\end{array}$ & $\begin{array}{l}(1980) \\
(1980) \\
(1980) \\
(1980) \\
(1987) \\
\text { (Indef.) }\end{array}$ & & \\
\hline USSR & $\begin{array}{l}\text { LMFBR: } \\
\text { LGR: } \\
\text { LWR: }\end{array}$ & $\begin{array}{r}0.95 \\
9.9 \\
10.9 \\
14.9 \\
6.9 \\
8.9\end{array}$ & $\begin{array}{l}(1980) \\
(1980) \\
(1981) \\
(\text { Indef.) } \\
(1980) \\
(1982)\end{array}$ & 20 & $(1980)$ \\
\hline Yugoslavia & LWR: & 0.62 & $(1983)$ & 9.3 & $(2000)$ \\
\hline Wor 1d & $\begin{array}{l}\text { LWR: } \\
\text { Other: }\end{array}$ & $\begin{array}{r}352 \\
55\end{array}$ & & & \\
\hline
\end{tabular}

(a) GWe of plants in commercial operation or scheduled for operation by the end of the year listed. Forecasts of nuclear power capacity were taken from the February 1980 issue of Nuclear News and recent issues of Nucleonics Week, The Energy Daily, Nuclear Engineering International, and Energy in Countries with Planned Economics.

(b) Startup of Tullnerfeld reactor vetoed by public vote in November 1978; future is uncertain. 
TABLE 2. Industrial Fuel Cycle Activities

\begin{tabular}{|c|c|c|c|c|c|c|c|}
\hline \multirow[b]{2}{*}{ Country } & \multirow{2}{*}{$\begin{array}{c}\text { Uranium } \\
\text { Mining } \\
\text { and Milling } \\
\end{array}$} & \multirow[b]{2}{*}{$\begin{array}{l}\text { Uranium } \\
\text { Enrichment }\end{array}$} & \multirow[b]{2}{*}{$\begin{array}{l}\text { Mox Fuels } \\
\text { Fabrication } \\
\end{array}$} & \multicolumn{2}{|c|}{ Spent Fuels } & \multicolumn{2}{|c|}{$\begin{array}{c}\text { Waste } \\
\text { Immobilization } \\
\end{array}$} \\
\hline & & & & $\begin{array}{l}\text { Storage and } \\
\text { Transportation }\end{array}$ & Reprocessing & Non-HLW & $\mathrm{HLW}$ \\
\hline Argentina & $x$ & & & & & & \\
\hline Australia & $x$ & Potential & & & & & \\
\hline Belgium & & & $x$ & & Potential & $x$ & Potential \\
\hline Brazil & Potential & Potential & & & & & \\
\hline Canada & $x$ & & & $x$ & Potential & $x$ & Potential \\
\hline $\begin{array}{l}\text { Central } \\
\text { African } \\
\text { Empire }\end{array}$ & $x$ & & & & & & \\
\hline China & $x$ & $x$ & & & & & \\
\hline Denmark & & Potential & & & & & \\
\hline $\begin{array}{l}\text { Federal } \\
\text { Republic of } \\
\text { Germany }\end{array}$ & $x$ & $x$ & $x$ & $x$ & $x$ & $x$ & Potential \\
\hline France & $x$ & $x$ & $x$ & $x$ & $x$ & $x$ & $x$ \\
\hline Gabon & $x$ & & & & & & \\
\hline India & $x$ & & & & $x$ & & $x$ \\
\hline Italy & $x$ & & $x$ & & Potential & & Potential \\
\hline Japan & $x$ & $x$ & $x$ & & $x$ & $x$ & Potential \\
\hline Mexico & $x$ & & Potential & & Potential & & \\
\hline Nether 1 ands & & $x$ & & & & & \\
\hline South Africa & $x$ & $x$ & & & & & \\
\hline Spain & $x$ & & & & & & \\
\hline Sweden & Potential & & & $x$ & & & \\
\hline United & & & & & & & \\
\hline Kingdom & & $x$ & $x$ & $x$ & $x$ & $x$ & Potential \\
\hline Turkey & Potential & & & & & & \\
\hline USSR & $x$ & $x$ & $x$ & & $x$ & & \\
\hline
\end{tabular}


TABLE 3. Spent Fuel Arisings Through December 1979

\begin{tabular}{|c|c|c|c|c|}
\hline Country & Type & $\begin{array}{l}\text { Cumulated } \\
\text { GWd } 1979(a)\end{array}$ & $\begin{array}{c}\text { Spent Fuel, } \\
t \mathrm{tM}(\mathrm{b})\end{array}$ & $\begin{array}{r}\text { Spent Fuel No } \\
\text { of Assemblies }\end{array}$ \\
\hline Argentina & PHWR & 556 & 339.0 & 2,221 \\
\hline Belgium & PWR & 2,191 & 200.1 & 678 \\
\hline Canada & PHWR & 7,196 & $2,500.0^{(d)}$ & 147,171 \\
\hline $\begin{array}{l}\text { Federal } \\
\text { Republic of } \\
\text { Germany }\end{array}$ & $\begin{array}{l}\text { BWR } \\
\text { PHWR } \\
\text { PWR }\end{array}$ & $\begin{array}{r}1,998 \\
172 \\
6,194\end{array}$ & $\begin{array}{r}245.4 \\
54.8 \\
630.2\end{array}$ & $\begin{array}{l}1,797 \\
1,115 \\
1,819\end{array}$ \\
\hline Finland & $\begin{array}{l}\text { BWR } \\
\text { PWR }\end{array}$ & $\begin{array}{l}153 \\
372\end{array}$ & $\begin{array}{l}17.0 \\
40.5\end{array}$ & $\begin{array}{l}108 \\
338\end{array}$ \\
\hline France & $\begin{array}{l}\text { FBR } \\
\text { GCHWR } \\
\text { GCR } \\
\text { PWR }\end{array}$ & $\begin{array}{r}291 \\
189 \\
5,234 \\
2,385\end{array}$ & $\begin{array}{r}6.6 \\
33.9 \\
4,799.2 \\
241.3\end{array}$ & $\begin{array}{r}177 \\
4,092 \\
410,837 \\
707\end{array}$ \\
\hline India & $\begin{array}{l}\text { BWR } \\
\text { CANDU }\end{array}$ & $\begin{array}{l}812 \\
187\end{array}$ & $\begin{array}{r}117.8 \\
93.5\end{array}$ & $\begin{array}{r}842 \\
6,948\end{array}$ \\
\hline Italy & $\begin{array}{l}\text { BWR } \\
\text { GCR } \\
\text { PWR }\end{array}$ & $\begin{array}{l}584 \\
772 \\
820\end{array}$ & $\begin{array}{r}89.0 \\
1,148.6 \\
109.7\end{array}$ & $\begin{array}{r}466 \\
100,774 \\
406\end{array}$ \\
\hline Japan & $\begin{array}{l}\text { BWR } \\
\text { GCR } \\
\text { LWCHWR } \\
\text { PWR }\end{array}$ & $\begin{array}{r}5,499 \\
527 \\
53 \\
4,385\end{array}$ & $\begin{array}{r}657.0 \\
543.0 \\
15.1 \\
555.1\end{array}$ & $\begin{array}{r}3,880 \\
47,653 \\
109 \\
1,476\end{array}$ \\
\hline Nether 1 ands & $\begin{array}{l}\text { BWR } \\
\text { PWR }\end{array}$ & $\begin{array}{l}173 \\
838\end{array}$ & $\begin{array}{l}25.8 \\
86.6\end{array}$ & $\begin{array}{l}503 \\
316\end{array}$ \\
\hline Pakistan & PHWR & 121 & 48.6 & 3,655 \\
\hline South Korea & PWR & 231 & 26.7 & 75 \\
\hline Spain & $\begin{array}{l}\text { BWR } \\
\text { GCR } \\
\text { PWR }\end{array}$ & $\begin{array}{r}945 \\
1,039 \\
466\end{array}$ & $\begin{array}{r}132.1 \\
618.7 \\
47.0\end{array}$ & $\begin{array}{r}760 \\
64,850 \\
202\end{array}$ \\
\hline Sweden & $\begin{array}{l}\text { BWR } \\
\text { PWR }\end{array}$ & $\begin{array}{r}2,866 \\
853\end{array}$ & $\begin{array}{r}327.4 \\
83.3\end{array}$ & $\begin{array}{r}1,867 \\
205\end{array}$ \\
\hline Switzerland & $\begin{array}{l}\text { BWR } \\
\text { PWR }\end{array}$ & $\begin{array}{r}712 \\
2,034\end{array}$ & $\begin{array}{l}108.1 \\
231.3\end{array}$ & $\begin{array}{l}661 \\
697\end{array}$ \\
\hline Taiwan & BWR & 378 & 71.5 & 452 \\
\hline $\begin{array}{l}\text { United } \\
\text { Kingdom }\end{array}$ & $\begin{array}{l}\text { AGR } \\
\text { FBR } \\
\text { GCR } \\
\text { SGHWR }\end{array}$ & $\begin{array}{r}1,076 \\
33 \\
18,559 \\
234\end{array}$ & $\begin{array}{r}162.5 \\
1.3 \\
21,281.8 \\
36.2\end{array}$ & $\begin{array}{r}2,747 \\
28 \\
3,707,139 \\
207\end{array}$ \\
\hline
\end{tabular}

(a) Data from Nucleonics Week, January 24, 1980, Ref. 1.

(b) Calculated from cumulative GWd using burnup-at-discharge and reactor efficiency factors given in Nucleonics Week, January 24, 1980, Ref. 2 and 3.

(c) Calculated from spent fuel weights and reactor parameters given in Nucleon ics Week, January 24, 1980, Ref. 2.

(d) Cameron, D. J., "The Management of High Level and Alpha-Bearing Wastes in Canada -- Past, Present and Future." Paper presented at the 5 th Meeting of the Technical Committee on High Level and Alpha-Bearing Wastes, Cadarache, France, October 1979, p. 3. 
TABLE 4. Waste Management R\&D Activities

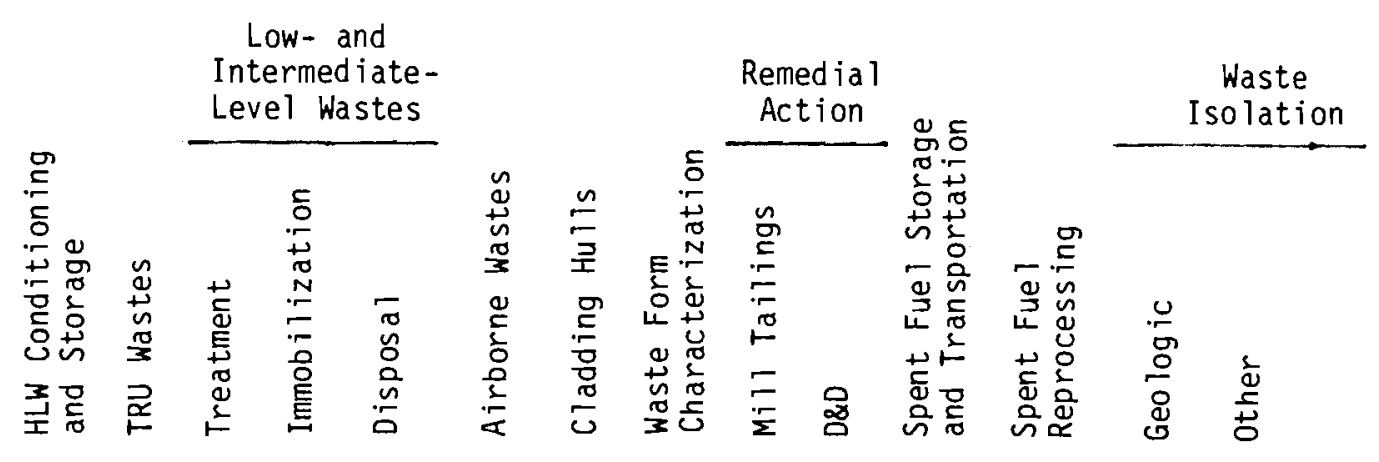

Country

\begin{tabular}{|c|c|c|c|c|c|c|c|c|c|c|c|c|c|c|}
\hline Argentina & & & $x$ & & & & & & & & & $x$ & & \\
\hline Australia & $x$ & & $x$ & & & & & $x$ & $x$ & & & & & \\
\hline Austria & $x$ & & $x$ & $x$ & & & & & & & & & $x$ & \\
\hline Belgium & & $x$ & & $x$ & & $x$ & $x$ & $x$ & & & $x$ & $x$ & $x$ & \\
\hline Brazil & & & & & & & & & & & & $x$ & $x$ & \\
\hline Canada & $x$ & $x$ & $x$ & $x$ & & $x$ & & $x$ & $x$ & & $x$ & $x$ & $x$ & $x$ \\
\hline Denmark & & & & & & & & & & & & & $x$ & \\
\hline Fin land & & & & $x$ & $x$ & & & & & & & & $x$ & \\
\hline France & $x$ & $x$ & $x$ & $x$ & & $x$ & $x$ & $x$ & & & & $x$ & $x$ & $x$ \\
\hline $\begin{array}{l}\text { Federal } \\
\text { Repub lic of } \\
\text { Germany }\end{array}$ & $x$ & $x$ & $x$ & $x$ & $x$ & $x$ & $x$ & $x$ & & $x$ & $x$ & $x$ & $x$ & $x$ \\
\hline India & $x$ & $x$ & $x$ & $x$ & & & $x$ & & & & & $x$ & $x$ & \\
\hline Italy & $x$ & $x$ & $x$ & $x$ & & & & $x$ & & & & $x$ & $x$ & \\
\hline Jap an & $x$ & $x$ & $x$ & $x$ & $x$ & $x$ & & $x$ & & $x$ & $x$ & $x$ & $x$ & $x$ \\
\hline Mexico & & & & & & & & & & & & $x$ & & \\
\hline Nether lands & & & $x$ & & & $x$ & & & & & & & $x$ & $x$ \\
\hline Spain & $x$ & & $x$ & $x$ & & & & & & & $x$ & $x$ & $x$ & \\
\hline Sweden & $x$ & $x$ & $x$ & $x$ & & & & $x$ & & & $x$ & & $x$ & \\
\hline Switzer land & & & & & & & & & & & $x$ & & $x$ & \\
\hline $\begin{array}{l}\text { United } \\
\text { Kingdom }\end{array}$ & $x$ & $x$ & $x$ & $x$ & & $x$ & $x$ & $x$ & & $x$ & $x$ & $x$ & $x$ & $x$ \\
\hline USSR & $x$ & $x$ & $x$ & $x$ & $x$ & $x$ & $x$ & $x$ & & & $x$ & $x$ & $x$ & $x$ \\
\hline CEC-Ispra & & $x$ & & & & & & & & $x$ & & & $x$ & \\
\hline Eurochem ic & $x$ & & & $x$ & $x$ & & $x$ & $x$ & & $x$ & & & & \\
\hline
\end{tabular}


TABLE 5. Membership in International Agencies* (February 1977)

\begin{tabular}{|c|c|c|c|c|c|c|}
\hline OECD/NEA & $\underline{O E C D / I E A}$ & $\underline{\text { CEC }}$ & CMEA & Eurochemic & Foratom & $\begin{array}{l}\text { Nordic } \\
\text { Council } \\
\end{array}$ \\
\hline \multicolumn{7}{|l|}{$x$} \\
\hline$x$ & $x$ & & & $x$ & $x$ & \multirow[b]{2}{*}{ - } \\
\hline \multirow[t]{2}{*}{$x$} & $x$ & $x$ & & $x$ & $x$ & \\
\hline & & & $x$ & & & \\
\hline \multirow[t]{3}{*}{$x$} & $x$ & & & & & \\
\hline & & & $x$ & & & \\
\hline & & & $x$ & & & \\
\hline$x$ & $x$ & $x$ & & $x$ & $x$ & $x$ \\
\hline$x$ & & & & & $x$ & $x$ \\
\hline \multirow[t]{2}{*}{$x$} & & $x$ & & $x$ & $x$ & \\
\hline & & & $x$ & & & \\
\hline$x$ & $x$ & $x$ & & $x$ & $x$ & \\
\hline \multicolumn{7}{|l|}{$x$} \\
\hline & & & $x$ & & & \\
\hline$x$ & & & & & & $x$ \\
\hline$x$ & $x$ & $x$ & & & & \\
\hline$x$ & $x$ & $x$ & & $x$ & $x$ & \\
\hline$x$ & $x$ & & & & & \\
\hline$x$ & $x$ & $x$ & & $x$ & $x$ & \\
\hline
\end{tabular}

* All countries listed belong to IAEA. 
TABLE 5. (Cont'd)

\begin{tabular}{|c|c|c|c|c|c|c|c|}
\hline Country & OECD/NEA & 0 OECD/IEA & CEC & CMEA & Eurochemic & Foratom & $\begin{array}{l}\text { Nordic } \\
\text { Council } \\
\end{array}$ \\
\hline Mongolia & & & & $x$ & & & \\
\hline Netherl ands & $x$ & $x$ & $x$ & & $x$ & $x$ & \\
\hline New Zealand & + & $x$ & & & & & \\
\hline Norway & $x$ & $x$ & & & $x$ & $x$ & $x$ \\
\hline Poland & & & & $x$ & & & \\
\hline Portugal & $x$ & & & & $x$ & $x$ & \\
\hline Rumania & & & & $x$ & & & \\
\hline Spain & $x$ & $x$ & & & $x$ & $x$ & \\
\hline Sweden & $x$ & $x$ & & & $x$ & $x$ & $x$ \\
\hline Switzerland & $x$ & $x$ & & & $x$ & $x$ & \\
\hline Turkey & $x$ & $x$ & & & $x$ & & \\
\hline USSR & & & & $x$ & & & \\
\hline United Kingdom & $x$ & $x$ & $x$ & & & $x$ & \\
\hline United States & $x$ & $x$ & & & & & \\
\hline Yugoslavia & + & & & + & & & \\
\hline
\end{tabular}

+ Special status 
TABLE 6. Nuclear Waste Management Highlights, March 1979 -- March 1980 Country or Organization Highlights

Australia

- Professor A. E. Ringwood's SYNROC development program is being supported by the IAEA ( $\$ 50 \mathrm{~K}$ during the first year for equipment) and the AAEC (funding for a staff of three). The AAEC is to cooperate in the program with scale-up of fabrication techniques and irradiation testing of the product.

Belgium

- The waste vitrification situation at Mol is as follows. Eurochemic is still responsible for solidifying the high-level wastes generated through 1974 by the Eurochemic fuel reprocessing plant. There are two types of waste: $67 \mathrm{~m}^{3}$ of Low Enriched Waste Concentrate (LEWC), typical of Purex wastes from reprocessing LWR fuels; and about $800 \mathrm{~m}^{3}$ of High Enriched Waste Concentrate (HEWC), high-aluminum wastes from reprocessing MTR fuels.

Two waste vitrification plants are to be built on the Eurochemic site at Mol. An AVM-type plant, to vitrify the $800 \mathrm{~m}^{3}$ of HEWC is to be built by the French for the Belgian government (Belgoprocess) with the limitation that no information or know-how is to be turned over to the other Eurochemic partners. The cost of the plant is to be funded through normal contributions to Eurochemic from the member states. Operation of the AVB at Mol is to be limited to Belgian personnel.

A Pamela process pilot plant is to be engineered and paid for by the Federal Republic of Germany. Eighty percent of the funds are to be provided by the Ministry of Research and Development and twenty percent by DWK. The Pamela process is being redesigned to produce a borosilicate glass and either glass beads or monolithic blocks, using existing Eurochemic LEWC. Startup of this plant is not expected until 1986.

Present plans are that the two vitrification plants at Mol will be totally independent of each other, with no shared utilities, services or buildings. 
TABLE 6 (contd)

Country or Organization

Highlights

Belgium (contd)

Brazil

EG\&G-Idaho and CEN/SCK are negotiating a contract to have special U.S. tests made in the slagging inc inerator at Mol starting in June or July 1980. Data are to be obtained on temperatures, pressures and flows in the system using simulated INEL wastes spiked with TRU elements.

- Brazil and the U.S. are negotiating toward a joint project to study radionuclide migration near a major thorium deposit in Brazil.

Denmark

- The utilities in Denmark have embarked on a 2-year study, ending in 1980 and funded at $\$ 10 \mathrm{M}$, to determine if Denmark has adequate waste disposal capability for nuclear power to be introduced into Denmark. Three or four salt dome sites will be investigated; the choice will be narrowed to two and deep drilling, seismic and geologic studies, and supporting work will be done. They are also having a conceptual design dome for a repository.

Federal Republic of Germany

- The "Gorleben hearings," in which groups of international nuclear critics and counter-critics-including U.S. representatives--debated the merits and risks of the Gorleben fuel disposal center, were held with the Minister-President of Lower Saxony and other senior government officials present. In midMay, Dr. Albrecht announced that further licensing activities for the fuel reprocessing facilities at Gorleben were to be suspended indef initely, but that work to license the repository could proceed.

Tentative agreement among the governors was later reached to abandon $\mathrm{plans}$ for the $1500-\mathrm{t}$ reprocessing plant at Gorleben and substitute several smaller $(400-t)$ plants at various sites. In a September report, the governors agreed that reprocessing of spent fuel elements including recycling of unspent nuclear fuels and final storage of the waste arising from reprocessing is feasible safetywise and necessary from the points of view of ecology and economy. 
TABLE 6 (contd)

Country or Organization

Federal Republic of Germany (contd)
Highlights

Efforts have been taken to ensure speedy construction of a reprocessing plant so that the temporary storage of spent fuel elements can be limited to the shortest possible time. The Gorleben salt dome is still the proposed site for the waste repository.

- The PTB (German equivalent of the U.S. National Bureau of Standards), assigned by the government to design, license and operate the Gorleben waste repository, has now been given a similar responsibility for the Asse mine. Interfaces with GSF, which has had sole responsibility for Asse, have yet to be defined.

- Special rooms and facilities may have to be prepared at Asse to allow retrievable storage of waste drums.

- Tests of a process for in situ immobilization of nonhigh-level wastes are planned for Asse. Five solution-mined cavities ( $10 \mathrm{~m}^{3}$ each) are to be filled with various cement-based slurries and simulated waste pellets. Core drillings will then be made into the cavities and host rock to evaluate such things as diffusion transport, waste-rock bonding, leaching characteristics of mixes and effects of heat on curing of the cements. A large-scale demonstration of the concept is planned after the small-scale studies are completed. The Germans would like to conduct "hot" radioactive tests on cements in support of this program.

- Startup of the Jupiter (reprocessing of HTGR fuels) pilot plant at Jülich is not anticipated before 1985 . The delay from the 1980-1981 time frame is attributed to the decision to license the facility.

- DWK is sponsoring the development of casks for a dry storage AFR concept. New, low cost casks fabricated by casting have been successfully tested.

- The Karlsruhe Nuclear Research Center has commissioned the ISA-Technik/Nuk leartechnik consortium to plan, build and assemble a medium-level waste laboratory consisting of a caisson as a contamination barrier and an integrated hot cell facility. The laboratory will be used to study medium-level waste products. 
TABLE 6 (contd)

Country or Organization

Japan

Sweden

Sweden

Switzer land

Union of Soviet Socialist Republics

United Kingdom
Highlights

Construction of a \$23-M facility for cryogenic distillation and pressurized cylinder storage of krypton was to be started at Tokai Mura in December 1979.

- About 100 Japanese companies have banded together to develop a 1,100-t/yr reprocessing $\mathrm{plant,}$ the nation's first fully commercial unit, by 1990 . The plant will cost an estimated $\$ 2.8$ billion. The project is to be managed by a consortium to be known as Nippon Gennen Service. Site selection and acquisition is expected to take about three years.

- Field tests of radionuclide transport in fractured rock at Studsvik have been completed. A second series of in situ experiments was to start in 1979.

- Sweden is proposing a \$10-M, 4-year multinational test program in the Stripa Mine. Canada, Switzerland and the U.S. expect to participate, and the NEA plans to coordinate the program.

- Present Swedish plans are to have a waste repository design by the year 2000, an operational repository by 2020 and shallow land storage for ILW by 1984-85.

- Public vote on a referendum May 20, 1979 gave $69 \%$ support to the government's amendments of the nuclear licensing laws. The amendments place increased controls on the expansion of nuclear power with requirements to establish a need for new nuclear plants and to provide satisfactory waste management plans before the issuance of licenses, but their passage is regarded as an endorsement of government policy to push ahead with nuclear power development.

- The U.S.S.R. is considering media such as rock salt, granite and sandstone as host media for mine repositories. Soviet criteria for siting repositories have recently been developed.

- The Flowers Commission recommended that responsibility for waste management R\&D be transferred from the UKAEA to another government department. The Department of the Environment has received this assignment and now administers all waste management R\&D funds. In addition to waste management R\&D, the Department of the Environment has functions roughly analagous to those of the NRC and EPA in the U.S. The new nuclear waste management branch is under the direction of Dr. F. S. Feates. 
TABLE 6 (contd)

Country or Organization

United Kingdom (contd)
Highlights

BNFL plans to commission a full-scale HLW vitrification plant at Windscale by the late 1980s. With design to be frozen in about 4 years, the British have not yet made a final selection of process. After a comparative analys is of the HARVEST and AVM processes, a decision on the choice of process for Windscale is to be made by mid-1981. A British visitor to the U.S. estimated about even odds on selection of HARVEST versus AVM. The U.K. has an agreement with France for a no-fee license to install the AVM process if BNFL selects that option. The decision is being postponed to see if the AVM plant at Marcoule still looks good after several more months' operation.

BNFL testing and development of HARVEST continues. Test and demonstration facilities in the construction stage include: a small hot pilot plant at Windscale that produces small blocks of radioactive glass for evaluation -- to be commissioned in about 2 years; and a full-scale mockup of the demonstration plant that tests handling equipment, etc. -- to be operational in about 2 years.

- The U.K. is also still evaluating various vitrification processes for installation at Dounreay, to treat HLW from the small FBR fuel reprocessing plant located there. FINGAL (HARVEST), ceramic melter and AVM concepts are currently favored.

- The fuel element development laboratory at Springfields has been given the charter to do nonradioactive HLW immobilization studies in support of Dounreay and Windscale.

- The U.K. is looking at some 20 sites for final disposal of nuclear waste. Preferred sites will be designated in 1984. First phase exploratory drilling at a site near Dounreay has been completed. Although not considered one of the most promising sites in the U.K. for a hard-rock repository, a second-phase exploratory drilling will probably also be done there. This is an action necessitated by public resistance to drilling in other locations. 
TABLE 6 (contd)

Country or Organization

United Kingdom

(contd)

Commission of the European Communities
Highlights

- Harwell researchers have successfully tested the use of microwave power in a continuous HLW vitrification process. The technique also uses a continuously replaced glass-former off-gas filter. Harwell is also starting design work on a joule-heated ceramic melter with plans to install one.

- With the first five-year indirect action waste management R\&D program ending in December 1979, the CEC has proposed a second five-year program. Emphas is is placed on treatment and immobilization of LLW, ILW, TRU wastes, cladding hulls and airborne wastes; characterization of waste forms; and waste isolation. Total CEC share of the indirect action's waste management budget over the period 1980-84 is to be about $\$ 60 \mathrm{M}$.

- U.S. Department of Energy and CEC representatives have decided that a formal agreement for information exchange in the field of waste management would be of mutual value. Negotiations and identification of specific technological areas for exchange are planned. 
NATIONAL AND INTERNATIONAL PROGRAM OVERVIEWS

Brief overviews of fuel cycle and waste management activities are provided for the following nations and international organizations.

$\begin{array}{ll}\text { Argentina } & \text { Netherlands } \\ \text { Australia } & \text { Spain } \\ \text { Austria } & \text { Sweden } \\ \text { Belgium } & \text { Switzerland } \\ \text { Brazil } & \text { United Kingdom } \\ \text { Canada } & \text { Union of Soviet Socialist Republics } \\ \text { Denmark } & \text { IAEA } \\ \text { Finland } & \text { Commission of European Communities } \\ \text { France } & \text { (including JRC-Ispra and European } \\ \text { Germany, Federal } & \text { OECD/NEA } \\ \text { Republic of (FRG) } & \text { Eurochemic } \\ \text { India } & \text { CMEA } \\ \text { Italy } & \text { United Reprocessors GmbH } \\ \text { Japan } & \text { Nuclear Transport Limited } \\ \text { Mexico } & \end{array}$

\section{ARGENTINA}

NUCLEAR FUEL CYCLE POLICY AND PROGRAMS

National objectives are to develop extensive nuclear power production capability and to achieve domestic self-sufficiency in production of uranium fuel and heavy water (for PHWRs). 
ORGANIZATION

The Comision National de Energia Atomica (CNEA), Buenos Aires (National Atomic Energy Commission) owns and operates all facilities.

\section{COMMERCIAL NUCLEAR ACTIVITIES}

1. Power production (GWe): 1981--0.93 PHWR, 2000--4.0 (23\%).

2. Uranium mining and milling (tU/yr): 1978--280, 1985--600.

3. Fabrication of $\mathrm{UO}_{2}$ fuels: At present, Argentine yellowcake is converted to $\mathrm{UO}_{2}$ pellets in the Federal Republic of Germany. The pellets are returned to Argentina for fabrication into fuel rods and assemblies.

FUEL CYCLE AND WASTE TREATMENT R\&D

1. Fuel reprocessing: Plans to construct an "experimental" reprocessing plant at the Ezeiza Atomic Centre near Buenos Aires were announced in December 1978 by the Atomic Energy Commission.

2. Waste treatment: The Argentine government has announced plans to build an experimental solidification plant for "high activity" wastes. (These were not defined. The plant is probably not intended for high-level waste.) Startup is expected in 1985.

\section{AUSTRALIA}

\section{NUCLEAR FUEL CYCLE POLICY AND PROGRAMS}

Australia has made no commitment to nuclear power station construction, but in Western Australia the Premier has announced that the state will need a 1000-MWe station by 1990, and a site near Perth has been selected. An eventual need for nuclear power is also projected for other states such as South Australia and Victoria. 
Australia has the potential of becoming one of the major uranium producing countries of the world, with reasonably assured resources estimated at $289,000 \mathrm{tU}$ recoverable at costs of less than $\$ 80 / \mathrm{kg}$. Additional resources are estimated at 44,000 t. Production capacity has the potential of rising to 20,000 tU/yr by 1990. Plans for increased uranium production for export, while receiving government support, have met with significant public opposition on environmental grounds and because of a perceived lack of demonstrated radioactive waste disposal technology.

As an adjunct to its uranium production potential, Australia is evaluating the feasibility of a uranium enrichment venture, perhaps in partnership with another country.

\section{ORGANIZATION}

The Australian Atomic Energy Commission (AAEC), affiliated with the Ministry of State for Minerals and Energy, was organized in the mid-1950s to promote development and utilization of the country's uranium resources and the products of atomic energy, to collect and distribute information on uranium and atomic energy and to undertake research in universities and elsewhere.

Nuclear research and development in Australia is carried out primarily at the AAEC Lucas Heights Research Establishment at Sutherland, New South Wales (near Sydney). As of May 1979, the Lucas Heights establishment had a staff of about 1100 in nine research divisions: Applied Mathematics and Computing, Centrifuge Enrichment Project, Chemical Technology, Engineering Research, Environmental Science, Instrumentation and Control, Isotopes, Materials, and Physics. The Materials Division has the major responsibility for scale-up of the SYNROC process for waste immobilization, with support (leaching studies) from Chemical Technology. The Chemical Technology Division, responsible for chemical processing, analytical chemistry, waste treatment and laser enrichment studies, employs about 60 people. 
The Australia National University at Canberra, where the SYNROC process was conceived, is primarily a research and graduate school. Basic funding for the university comes from the Commonwealth Government. Additional R\&D program funding comes from such organizations as the Australian National Science Foundation. The Research School of Earth Sciences has about 30 doctoral candidates and an equal number of academic faculty.

\section{COMMERCIAL NUCLEAR ACTIVITIES}

1. Power production (GWe): 2000--1.0.

2. Uranium Mining and Milling: Potential capacities (tU/yr): 1979--500, $1981--1800,1985--11,800$ and 1990--20,000.

\section{FUEL CYCLE AND WASTE MANAGEMENT R\&D}

During the late 1950s and early 1960s, the AAEC carried on a program to develop gas-cooled high temperature reactors and started studies of reprocessing high temperature fuels. Since the HTR program was dropped, the AAEC has not had much interest in fuel reprocessing.

Currently, the AAEC's main interests in fuel cycle and waste management $R \& D$ are centered in:

1. Development of a process to produce uranium hexafluoride by catalyzed oxidation of $\mathrm{UF}_{4}$.

2. Development of gas centrifuge and laser technology for uranium enrichment.

3. Improvements in the management of wastes from uranium mining and milling. These projects include:

- Study of radium and heavy metal concentrations in tailings and process waste solutions.

- Determination of factors affecting the natural leaching of radium from tailings. 
- Determination of radon release from ores and tailings under various conditions; assessment of the feasibility of removing radon from air streams.

- Studies of surface hydrology at prospective mines and mills.

- Studies of naturally occurring nuclide migration and movement through the food chain. Australia has large ore bodies located near the surface in areas subject to high seasonal rainfall and periodic flooding. Past movement of radionuclides $\left({ }^{238} \mathrm{U}\right.$, ${ }^{234} \mathrm{U}$ and ${ }^{230} \mathrm{Th}$ ) under these extreme (but natura 1) conditions is being analyzed to provide a basis for the construction of a model of radionuclide movement through clay over a time span of about one-half million years.

- Investigating the use of reverse osmosis to concentrate dilute aqueous wastes.

4. Development of the SYNROC process for immobilizing high-level wastes. SYNROC is formed by melting 5-10 w/O HLW calcine with a mixture of synthetic minerals such as perovskite, barium felspar, zirconia and hollandite about $1300^{\circ} \mathrm{C}$. In cold studies, the product has shown high resistance to leaching by brines at temperatures of $350-400^{\circ} \mathrm{C}$ and pressures of 100 bar. Work on SYNROC was initiated by scientists at the Australia National University who proposed that the complete process include the following steps:

- Mix HLW calcine with the synthetic mineral ingredients; place the mixture in a thick-walled nickel cylinder and uniaxially cold press to about $70 \%$ of theoretical density.

- Close the open end of the cylinder with a nickel lid using a thin copper gasket to produce a seal.

- Hot-press at a temperature of $1200-1300^{\circ} \mathrm{C}$, producing crystalline SYNROC sealed inside a nickel container. 
Present plans for process development are as follows:

- The group at the university will continue their small-scale test efforts and theoretical studies.

- The Materials Division at Lucas Heights has started on cold scale-up tests and intends to produce kilogram-size samples by the end of 1979. Lucas Heights personnel also plan to conduct small hot cell evaluations of radiation damage, etc.

- Lucas Heights personnel hope to arrange for large-scale radioactive tests by another country, perhaps the U.S.

\section{$\underline{\text { AUSTRIA }}$}

\section{NUCLEAR FUEL CYCLE POLICY AND PROGRAMS}

The Austrian utilities and government have been planning to install a number of nuclear power stations. In a November 1978 plebiscite, however, the Austrian voters rejected by a small margin the startup of the country's first power station (Tulinerfeld near Vienna) leaving the future of Austrian nuclear power highly uncertain.

\section{SELECTED AGENCIES AND NUCLEAR RESEARCH CENTERS}

- Österreichische Studiengesellschaft für Atomenergie GmbH (SGAE), Vienna (Austrian Company for Atomic Energy Studies)

- SGAE Forschungszentrum Se ibersdorf, near Vienna (Seibersdorf Research Center)

- International Atomic Energy Agency (IAEA), Vienna. 
COMMERCIAL NUCLEAR ACTIVITIES

If the Austrians reverse the 1978 Tullnerfeld decision in the next few years, spent fuels are to be reprocessed at the La Hague plant in France. Vitrified waste and recovered uranium are to be returned to Austria; recovered plutonium, although Austrian property, would remain at La Hague temporarily.

\section{WASTE TREATMENT R\&D}

1. HLW solidification: At Seibersdorf, laboratory-scale R\&D efforts continue to develop ceramic coatings for waste calcine particles and to develop a vitrification process.

2. Also at Seibersdorf treatment of non-high-level wastes includes:

- immobilization in concrete and bitumen

- incineration of solid wastes.

\section{WASTE DISPOSAL}

Austria's objective is to evaluate the feasibility of providing a waste repository. Kernkraftwerks-Planungsgesellschaft has been assigned to search for suitable repository sites (granite formations are being emphasized). Seibersdorf is conducting supporting R\&D on heat transfer, corrosion, diffusion, barrier materials and risk analysis.

\section{BELGIUM}

\section{NUCLEAR FUEL CYCLE POLICY AND PROGRAMS}

The Belgian government and utilities are working toward well-rounded advanced reactor and fuel cycle capability through participation in multinational projects such as the Dragon HTR (OECD), Kalkar LMFBR (FRG and Netherlands) and the Eurodif enrichment plant (France and other partners); and development of domestic fuel reprocessing, MOX fuel fabrication, waste treatment and geologic waste disposal facilities. 
Fuel reprocessing and waste management plans are based on the following assumptions:

1. The Eurochemic fuel reprocessing plant will be modernized and used by Belgium to treat domestic fuels, recycling the plutonium product to domestic LWRs or to FBRs. Startup is projected for 1984.

2. Before turning all their facilities over to Belgium in 1982, Eurochemic will build an AVM-type waste vitrification plant at Mol. This facility will solidify the existing HLW left from earlier Eurochemic plant operations and then will be used by Belgium to solidify LWR high-level wastes.

3. A central facility will be constructed for the treatment and intermediate storage of process concentrates (slurries, resins, etc.) and medium-level waste.

4. Maximum recovery of plutonium from waste will be sought, and residual materials will be treated by incineration at very high temperatures.

5. An underground long-term storage site will be constructed for high-level treated waste and plutonium fuel fabrication waste. Deep clay formations are at present being investigated.

6. Low-level treated wastes will be discharged into the Atlantic 0cean.

\section{ORGANIZATION}

Government sponsored nuclear R\&D in Belgium is coordinated and performed primarily by the Nuclear Energy Research Center (Centre d'Étude de l'Énergie Nucléaire, CEN/SCK) at Mol. Commercial fuel cycle and waste management activities are handled by companies owned and controlled jointly by the government (through CEN/SCK) and by Synatom, a joint venture of the three principal utility groups in Belgium. It is anticipated that these companies (Belgonucleaire, Belgowaste and an unnamed fuel reprocessing company) will be brought together under a government/Synatom holding company, perhaps to be known as Belgofuels. 
Belgium also provides a home for the Commission of the European Communities (CEC, Brussels), the European Company for the Chemical Reprocessing of Irradiated Fuels (Eurochemic, Mol) and a PAMELA waste vitrification pilot plant to be built in Eurochemic space by the German fuel cycle company, DWK.

\section{COMMERCIAL NUCLEAR ACTIVITIES}

1. Power production (GWe): 1980--1.65 LWR, 1985--5.5 (45\%). (a)

2. Uranium enrichment: Belgium is part owner of the Eurodif gaseous diffusion plant in France.

3. MoX fuels: The Belgonucleaire plant at Dessel fabricates MoX fuels for recycle to LWRs. Capacity is $60 \mathrm{t} / \mathrm{yr}$.

4. Fuel reprocessing: The Eurochemic plant at Mol, Belgium, with a capacity of $60 \mathrm{tHM} / \mathrm{yr}$ of low-enriched uranium fuels that was operated from 1966 to 1974, is to resume operation under Belgium ownership in 1984 .

5. HLW solidification: The Eurochemic Company (OECD/NEA sponsored) is obligated to solidify the high-level liquid waste remaining from the fuel reprocessing operations of the Eurochemic plant at Mol, Belgium and plans to build a French AVM-type vitrification plant at Mol. Because Eurochemic is to transfer ownership of all their facilities at Mol to Belgium by mid1982, and because the Eurochemic AVM plant is not scheduled for startup before 1983-84, a Belgian company is to assume responsibility to vitrify the old Eurochemic plant waste $\left(800 \mathrm{~m}^{3}\right)$.

6. Non-high-level waste treatment:

- Bituminization: CEN/SCK operates a batch plant and Eurochemic has placed in service a continuous plant, "EUROBITUM," for cladding and other intermediate-level wastes. EUROBITUM capacity is $650 \mathrm{~m}^{3} / \mathrm{yr}$.

- Spent solvent treatment: Eurochemic is operating the "Eurowatt" solvent treatment plant $\left(1 \mathrm{~m}^{3} /\right.$ day) for conversion of used Purex solvent to forms suitable for disposal.

(a) Percent of national electrical power production capacity. 


\section{FUEL CYCLE AND WASTE MANAGEMENT R\&D}

Fuel cycle and waste management R\&D in Belgium is concentrated in the Mol area, where the following major programs are proposed or in progress.

\section{Fuels Fabrication}

Belgonucleaire operates pilot-scale facilities at Mol for developing MOX fuel fabrication technology.

Treatment of Non-High-Level Wastes

Non-high-level waste treatment studies by CEN/SCK include:

1. Treatment and immobilization of intermediate-level wastes from chemical fuel decladding operations.

2. Immobilization of non-high-level wastes (development of a waterless cement matrix).

3. Incineration of solid wastes, including Pu-contaminated materials.

4. Control of volatile radionuclides in the off-gas from nuclear reactors and fuel reprocessing $\mathrm{plants.}$

5. Treatment and transport of spent LMFBR fuels.

\section{WASTE DISPOSAL}

With co-sponsorship of CEC, Belgium is developing clay repository technology (site and media characterization, corrosion effects, repository design, risk analysis and in situ tests) and intends to have a test repository operational at Mol by 1983. The work is coordinated by CEN/SCK.

Evaluation of preliminary tests indicates that tunnels and underground facilities can be constructed in the Boom clay formations at Mol, at depths up to $250 \mathrm{~m}$, and that a thermal load of about $15 \mathrm{~kW}$ per hectare can be tolerated. Heater experiments and the construction of a test chamber ( $350 \mathrm{~m}$ long by $30 \mathrm{~m}$ wide) under the Mol site are planned. 


\section{BRAZIL}

\section{NUCLEAR FUEL CYCLE POLICY AND PROGRAMS}

The Brazilian government that took office March 15, 1979 intends to continue the previous program of nine nuclear units, a nozzle enrichment plant, a factory to manufacture heavy nuclear components and a reprocessing plant. Most of these facilities will be constructed with the aid of West German technology. The nuclear program has the following objectives:

- transfer technology via joint Brazilian/West German ventures

- assure the building of nuclear plants

- make feasible the fabrication of nuclear components and nuclear fuel

- consolidate national capabilities in design, construction and operation of nuclear plants

- centralize services for design and procurement of equipment.

However, a Parliamentary Commission of Enquiry is investigating all aspects of Brazil's nuclear program. Criticism has focused on ballooning costs of the nuclear plants under construction, and doubts have ar isen about the need for all nine of the proposed units. Opponents of the program point to the hydroelectric potential, estimated at $200,000 \mathrm{MW}$, with only $23 \%$ presently committed to use.

Brazil's resources of uranium are now estimated at 200,000 t. The country's first uranium processing venture, involving development of a mine and mill near Pocos de Calda, Minas Gerais state, is moving ahead. The mill should be in operation in 1 ate 1979 and will handle $250 \mathrm{t}$ of ore a day, producing $500 \mathrm{tU} / \mathrm{yr}$. 


\section{ORGANIZATION}

Nuclear power policy is planned, executed and controlled through the Brazilian Ministry of Mines and Energy. Directly subject to the Ministry is the Brazilian Nuclear Energy Commission (CNEN), which has regulatory, standardization, licensing, planning, surveillance, safety evaluation and operator training functions.

Also subject to the Ministry are two companies responsible for the execution of the program: Electrobrás, a holding of the Brazilian electricity utilities, and Nuclebrás, a federal nuclear power enterprise. Nuclebrás is responsible for plant engineering, project preparation, civil construction and equipment erection. To implement various facets of the nuclear program, Nuclebrás formed four subsidiaries which are joint venture companies with other firms:

- Nuclen (75\% Nuclebrás, 25\% KWl) manages nuclear power plant design and construction, and coordinates technology transfer in this area.

- Nuc lep (75\% Nuclebrás, 25\% European consortium) builds reactor components.

- Nustep (50\% Nuclebrás, 50\% Steag) covers commercial exploitation of the Becker jet-nozzle uranium enrichment process developed in Germany.

- Nuclei (75\% Nuclebrás, 15\% Steag, $10 \%$ Interatom) builds and operates a demonstration enrichment plant in Brazil.

\section{COMMERCIAL NUCLEAR ACTIVITIES}

1. Power production (GWe): 1980--0.63 LWR, 1987--3.1 and 2000--60 (45\%).

2. Uranium mining and milling (tU/yr): 1985--385.

\section{FUEL CYCLE AND WASTE MANAGEMENT R\&D}

1. Uranium enrichment: A joint Brazilian/West German pilot plant to demonstrate the Becker nozzle process is being built by Nuclei. Capacity will be 250 tSWU/yr. Startup is expected in 1983-84. Also, Nustep is 
currently constructing a facility at the Karlsruhe Nuclear Research Center for erecting and testing separation stages three times larger than those in the demonstration plant.

2. Uranium hexafluoride plant: Contract negotiations are under way with an unspecified French company for a uranium hexafluoride conversion facility. Startup is planned for 1983.

3. Fuel reprocessing: Nuclebras is building a 10-kgU/day pilot reprocessing plant in the Rio de Janeiro area. Design and technical assistance have been provided by West Germany. Startup is planned for 1984 .

4. Thorium deposit study: A Department of Energy grant has provided funds for a joint New York University/Pontificia Universidade Catolica preliminary study of the migration of nuclides from a rich thorium deposit located at Morro do Ferro.

5. Brazil has three research nuclear reactors in use, and the four nuclear institutes have the following principal fields of activity:

- Instituto de Energia Atomica--pure and applied nuclear research

- Instituto de Engenbaria Nuclear--pure and applied nuclear research

- Instituto de Radioprotecao e Dosimetria--radiological safety, protection and dosimetry

- Centro de Desenvolvimento de Tecnologia Nuclear de Nuclebras--applied research and industrial development of uses of atomic energy.

\section{CANADA}

\section{NUCLEAR FUEL CYCLE POLICY AND PLANS}

Canada has been aggressive in building a nuclear power industry and an export business based on the Canada deuterium uranium (CANDU) PHWR system. 
PHWRs use natural uranium $\mathrm{UO}_{2}$ fuels and employ heavy water as the moderator and coolant. Except for the Gentilly-1 (266 MW $)$ HWLWR power reactor in Quebec, all Canadian power stations operating or planned are designed for the CANDU concept.

Past Canadian policy has been to store spent CANDU fuels owned by the utility in water-filled bays at the power generating sites, deferring any serious work on reprocessing on the grounds that reprocessing of CANDU fuels was not economic. Current plans are that spent fuels will be transferred from the reactor fuel basins to a centralized interim storage facility at a federal "Fuel Cycle Center" which might be owned and operated by either the utility or the federal government. Ontario Hydro plans to build such a storage facility and is designing for future expansion capacity to meet Canadian needs well into the next century.

Long-term Canadian policy assumes the eventual need to recover plutonium and uranium from spent reactor fuels. Hence it is assumed that the Fuel cycle Center would include federally-owned reprocessing, refabrication and waste treatment facilities.

Canadian policy also assumes the eventual need for geologic disposal of either solidified HLLW (probably as glass) or unreprocessed spent fuel elements. The reference matrix for waste disposal studies is a solid matrix incorporating the fission products and other residues from reprocessing, but disposal of alternative waste forms is also being considered.

It is believed that the Th- ${ }^{233} U$ fuel cycle, with spent fue 1 reprocessing, can be used efficiently in the CANDU-type reactor system without substantial changes in reactor design. A major Canadian objective is to develop the thorium-burning CANDU and to develop the full thorium cycle in a CANDU reactor by the mid 1990 s. 


\section{ORGANIZATION}

Atomic Energy of Canada Limited (AECL), a federal agency, is responsible for the development of nuclear power systems to meet Canadian needs. Organized as a "Crown Company" in 1952, AECL's stock is held by the Minister of Energy, Mines and Resources. The company is governed by a board of directors drawn from commerce, industry, universities and utilities. In 1978, AECL was reorganized into a holding company with four subsidiaries:

1. AECL Research Company is responsible for the Chalk River and Whiteshe11 Research Laboratories. Whiteshell is responsible for all radioactive waste management R\&D except that done for reactor wastes which has been assigned to Chalk River.

2. AECL Engineering Company is responsible for design and marketing of the CANDU reactor system.

3. AECL Chemical Company is responsible for the Canadian heavy water plants.

4. AECL Radiochemical Company is responsible for radioisotopes and other medical applications.

Other Canadian organizations with major roles include:

1. Atomic Energy Control Board, a federal government agency with responsibility for safety, security and environmental concerns.

2. Ontario Hydro, a utility headquartered in Toronto, has made a major commitment to nuclear power production and works closely with AECL in areas of technology that are of direct concern to a nuclear utility.

3. Geologic Survey of Canada is a branch of the Department of Energy, Mines and Resources.

4. Mining Research Laboratories of Ottawa is also part of the Department of Energy, Mines and Resources.

The development program for fuel and waste disposal is jointly sponsored by the federal government and the province of Ontario. Policy decisions and 
approvals with respect to field research are made by a Four-Party Coordinating Committee representing the Federal Department of Energy, Mines and Resources; AECL; the Ontario Ministry of Energy; and Ontario Hydro.

A Technical Advisory Comittee of ten distinguished Canadian scientists, selected from nominations by six major Canadian professional associations, has been appointed by $A E C L$. This committee, which covers a wide range of disciplines, has a mandate to review the program in detail and make its findings available to the public.

\section{COMMERCIAL NUCLEAR ACTIVITIES}

1. Power production (GWe): 1980--4.75 PHWR (CANDU) and BLWR, 1990--15, $2000--45$ and $2025--100$.

2. Uranium mining and milling (tU/yr): 1978--6450 and 1985--12,500.

3. Spent fuel storage: Ontario Hydro plans to build a centralized storage facility to allow storage in a water pool for 5 years and natural draft storage in air for 50 years.

4. Management of reactor wastes: Ontario Hydro's Radioactive Waste Operations Site at the Bruce Power Station has facilities for waste incineration, compaction and in-ground storage.

\section{FUEL CYCLE AND WASTE MANAGEMENT R\&D}

Canada is active in many areas of research and development summarized in the following sections.

Spent Fuel Handling and Storage

$A E C L$ is testing advanced techniques for packaging and storing spent fuels. Present programs emphasize:

1. Single- and multi-barrier canister development (Whiteshe11).

2. Testing of in-air storage (Whiteshel1). Chalk River also has stored spent CANDU fuels in air in concrete-lined holes in the ground. 
Spent Fuel Reprocessing

Whiteshe 11 has recently assembled a 300-g/day mini fuel reprocessing plant with six banks of mini mixer-settlers. It is to be installed in hot cells and used for Thorex process studies and for preparation of Thorex HLW to be used in vitrification tests.

Treatment of High-Level Wastes

AECL's Chalk River Laboratories studied the incorporation of fission products in aluminosilicate glasses about 20 years ago. In 1960, glass blocks containing high-level fission products were placed in swampy ground below the water table. Water samples taken since that time have shown almost negligible fission product leach rates.

Whiteshell investigators are currently studying the immobilization of spent fuel wastes in glasses and ceramic materials. Their objective is to develop an in-can melting process for high-activity wastes from reprocessing thorium fuels, with design and construction of a pilot-stage immobilization plant to start in 1980. Whiteshell also has a waste form characterization program under way.

Treatment of Other Wastes

Other waste treatment studies include:

1. Treatment and immobilization of reactor wastes by reverse osmosis, combustion or bituminization (Chalk River).

2. Recovery of volatile radionuclides from fuel reprocessing operations and incorporation of noble gases in solids such as zeolites (Whiteshe11).

3. Management of uranium mill tailings, with work on radium control, environmental impacts and use of grout around tailings ponds (various organizations). 


\section{Waste Disposal}

The objective of Canadian waste disposal R\&D is to verify that the disposal of radioactive wastes in deep, stable geologic formations will create no adverse effects on man or the environment at any time. A specific goal is to commission a commercial geologic repository for spent fuels and/or high-level and TRU wastes. Main milestones include complete concept ver if ication--1981, complete site selection for a repository--1984, start up a test repository-1990s and commission a commercial repository--about 2000. Major participants are Whiteshell (in charge) and Department of Energy, Mines and Resources (geological and geophysical studies).

Many potential repository sites have been located, most of them in granite formations in the Precambrian shield of Ontario Province. Others are in salt formations. Present efforts are directed toward showing that geologic disposal is safe and viable and narrowing the number of potential sites. A test site has been established in a small granitic body at White Lake to permit testing equipment and concepts. Recently, approval has been given to conduct research drilling at Atikokan, Ontario, to test rock formations for possible disposal sites.

Areas of major R\&D emphasis include repository site characterization, radionuclide migration, hydrology, thermal and mechanical properties of rock formations, repository design and borehole plugging.

\section{DENMARK}

\section{NUCLEAR FUEL CYCLE POLICY AND PROGRAMS}

In 1976 the Minister of Energy presented an energy plan to Parliament which called for five nuclear power stations to be completed by 1995 . Because of public opposition, however, the decision to introduce nuclear power was postponed several times until early 1980. At that time, the government determined that nuclear power plant construction was to be deferred indefinitely. 
In the meantime, the utility organizations Elsam and Elkraft have continued to plan for nuclear power. They have investigated potential power station sites and are sponsoring design and feasibility studies for a salt dome repository.

\section{ORGANIZATION}

The Atomenergikommisionen (Danish Atomic Energy Commission), located in Copenhagen, has overall reponsibility for nuclear energy matters. Research and development in the nuclear field is performed primarily by the Ris $\varnothing$ Research Establishment at Roskilde.

\section{WASTE MANAGEMENT}

Danish investigators (Ris $\varnothing$ Research Establishment, Roskilde) have been studying radioactive waste treatment and disposal for a number of years. In fact, they made the first known tests of a joule-heated ceramic melter for vitrifying simulated HLLW. They are currently interested in the treatment of low-level wastes, TRU properties and geologic disposal.

In early 1978, Danish utilities asked the French engineering company, Geostock, to prepare a conceptual design of a waste repository placed in a salt dome in Jutland, Denmark. The sponsors estimated the need for disposal of $750 \mathrm{~m}^{3}$ of radioactive $\mathrm{glass}$ between the years 2020 and 2060 and assumed 20 years' storage prior to placement in the repository.

The Danish government has advised the Danish utilities that a suitable national solution to the waste disposal problem would be required prior to consideration of any application to build nuclear reactors. In a 1977 response, Elkraft and Elsam initiated a two-phase study of Denmark's waste disposal potential. Phase I, a preliminary evaluation of waste disposal practices and programs, has been completed with the publication of a report entitled "Disposal of High-Level Waste from Nuclear Power Plants in Denmark." Phase II, a two-year project funded at $\$ 10 M$ by the utilities, is to be completed in 1980. The $\mathrm{plan}$ is to look at four salt domes in Denmark, select two sites, complete an initial design, and do some field work, including drilling two or three boreholes. 
The study is based upon the following considerations:

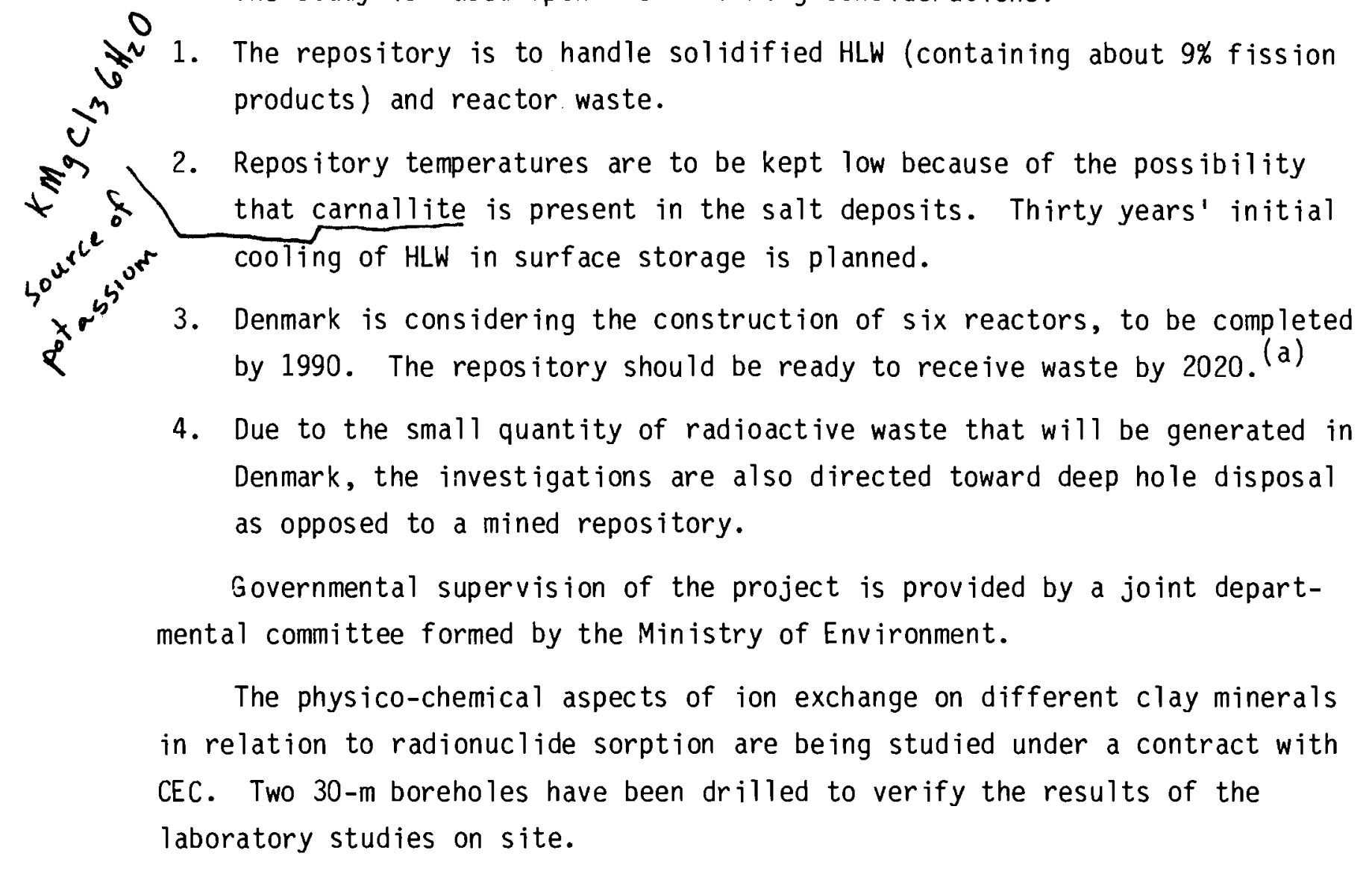

\section{FINLAND}

\section{NUCLEAR FUEL CYCLE POLICY AND PROGRAMS}

Finland has purchased nuclear power stations (LWRs) from the Soviet Union and Sweden. Spent fuel from the Soviet-built reactors is returned to the USSR for reprocessing and disposal of the wastes. Finland may purchase reprocessing service abroad for spent fuels from their Swedish-built reactors.

\section{SELECTED RESEARCH CENTERS}

- Technical Research Center of Finland, Espoo.

(a) In February 1980 the Danish prime minister announced that Denmark has abandoned a nuclear energy program. 
COMMERCIAL NUCLEAR ACTIVITIES

Power production (GWe): 1980--2.16 LWR (35\%) and 1985--7.

\section{WASTE TREATMENT R\&D}

The Technical Research Center at Espoo is studying encapsulation of reactor wastes in bitumen and concrete.

WASTE DISPOSAL

Because Finland may have to accept solidified HLW from foreign reprocessors of Finnish spent fuel, the feasibility of a crystalline rock repository is being evaluated. Support R\&D includes:

- risk assessment studies

- migration of radionuclides

- economic evaluation of alternatives.

\section{FRANCE}

NUCLEAR FUEL CYCLE POLICY AND PROGRAMS

France is very aggressive in developing nuclear power capability and in exporting equipment, plants and technology. Present emphas is is on installation of PWR power stations -- 30 identical 950-MW units are scheduled to come on-line in the future, one every two months. Emphas is is also being placed on expansion of LMFBR capacity (25 GWe by the year 2000), expansion of uranium enrichment and fuel reprocessing capacity to satisfy foreign and domestic requirements, and development of industrial waste treatment technology and plants.

National plans for waste management are:

- to vitrify all HLLW, provide interim storage for the waste glass canisters in concrete wells, then isolate in a suitable geologic formation 
- inter im storage is planned for up to 30-50 years with forced cooling and another 50 years with natural convection cooling

- to process low-level liquid wastes by conventional techniques, produce a decontaminated stream which can be discharged into the environment and a radioactive concentrate which will be immobilized in bitumen or concrete and stored

- if feasible, to develop and use processes for isolating alpha-emitters.

\section{ORGANIZATION}

The French Atomic Energy Commission (Commissariat a L'Énergie Atomique, CEA), operating under the direct authority of the Ministry of Industry and Research, is responsible for controlling all nuclear activities from research to defense. Commercial fuel cycle activities, once managed by the CEA, are now the responsibility of a CEA subsidiary, COGEMA (Compagnie Générale des Matières Nucléaires). COGEMA was formed in January 1976, to manage the CEA fuel cycle complex on an industrial basis. The policy is to offer integrated services covering the entire nuclear fuel cycle, including fuel management, and to develop an active exporting policy in this field. Company activities consequently cover uranium mining and exploration, enrichment (participation in Eurodif, Sofidif, Coredif and operation of Pierrelatte), reprocessing (ownership and operation of the La Hague and Marcoule fuel reprocessing plants), fuel fabrication, transportation of radioactive materials, and engineering and construction of fuel reprocessing plants through its subsidiary Société Générale pour les Techniques Nouvelles (SGN). SGN has acted as contractor for reprocessing plants in Japan and Pakistan (project cancelled) as well as in France and has been active in design and development of equipment for reprocessing and vitrification plants.

COGEMA is an equal shareholder with BNFL (UK) and KEWA (FRG) in United Reprocessors $\mathrm{GmbH}$. 
Research and development in the areas of fuel reprocessing and waste management are handled primarily by CEA's Chemical Division, which is headquartered at the Fontenay-aux Roses Nuclear Research Center (CEN-FAR). Fuel reprocessing and waste treatment centers and research centers doing waste management research and development include:

1. Cadarache Centre d'Études Nucléaires, St. Paul-les-Durance (Cadarache Nuclear Research Center)

2. Fontenay-aux-Roses Centre d'Études Nucléaires (FAR), Par is (Fontenay-auxRoses Nuclear Research Center)

3. Grenoble Centre d'Études Nucléaires, Grenoble (Grenoble Nuclear Research Center)

4. La Hague Centre, near Cherbourg

5. Marcoule Centre, Bagnols-sur-Ceze

6. Saclay Centre d'Études Nucléaires, Gif-sur-Yvette (Saclay Nuclear Research Centre).

Two other CEA divisions with major waste management responsibility are:

1. Agence Nationale de Gestion des Dechets (A.N.G.D.). The National Agency of Waste Management was formed in late 1979 by the French government and replaces the Office of Waste Management which was responsible for development, installation and operation of intermediate storage facilities and geologic repositories. A.N.G.D. will have full responsibility for final disposal of nuclear waste.

2. L'Institut de Protection et de Sûreté Nucléaire (I.P.S.N.). The Institute of Nuclear Protection and Safety is charged with safety analysis for nuclear installations and developing regulations.

\section{COMMERCIAL NUCLEAR ACTIVITIES}

1. Power production (GWe): 1980--2.2 (GCR), 0.07 (GCHWR), 0.23 (LMFBR) and 10.9 (LWR); 1983--1.43 (LMFBR); 1986--41.8 (LWR), and 2000--25 (LMFBR). 
2. Uranium enrichment:

- Pierrelatte and Eurodif gaseous diffusion plants. (Eurodif is a multinational project owned by Belgium, France, Iran, Italy and Spain.)

- A CEA pilot plant (50-100 tSWU/yr) is to be built to demonstrate a new French chemical exchange process which operates efficiently only for low enrichments. Startup is planned for 1983.

3. Fuel fabrication: The Cadarache MoX plant makes fuels for the French LMFBRs. Capacity is $15 \mathrm{t} / \mathrm{yr}$ for LWR fuels; $5 \mathrm{t} / \mathrm{yr}$ for FBR fuels.

4. Spent fuel reprocessing:

- UP-1 (COgEMA, Marcoule) is designed for natural uranium, gas-graphite reactor fuels. Capacity is 900 to $1200 \mathrm{tHM} / \mathrm{yr}$.

- PURR (COgema, Marcoule) is a new plant designed for MoX fuels from fast breeder reactors. Design capacity is $100 \mathrm{tHM} / \mathrm{yr}$. Startup is planned for 1989-90.

- SAP (CEA, Marcoule) is a pilot plant used for process development. Current effort supports France's FBR fuel cycle program. Capacity is $25 \mathrm{~kg} /$ day.

- UP-2 (COGEMA, La Hague) is designed and constructed for natural uranium, gas-graphite reactor fuels. UP-2 now has a chop-leach head-end to allow treatment of LWR oxide fuels. Present capacities are $1000 \mathrm{tHM} / \mathrm{yr}$ for natural uranium metal fuels and $400 \mathrm{tHM} / \mathrm{yr}$ for oxide fuels. Expansion of the oxide head-end to $800 \mathrm{tHM} / \mathrm{yr}$ capacity is planned. COGEMA intends to reprocess gas-graphite fuels only at Marcoule in the future, leaving UP-2 for LWR fuels. 
- UP-3 (COGEMA, La Hague) is a twin-line plant being built to handle LWR oxide fuels. The first line, UP-3A, is to start up in 1986 and is to service foreign customers. UP-3B, to come on-1ine in 1989-90, will handle domestic French fuels. Each line is sized at $800 \mathrm{thM} / \mathrm{yr}$.

- AT-1 (COGEMA, La Hague) is a pilot-scale plant (200 kg/yr) used to reprocess Rapsodie (LMFBR) spent fuels.

5. High-level waste solidification--AVM Plant (Marcoule):

AVM uses a rotary-kiln calciner coupled with a semicontinuous metallic melter to produce borosilicate glass blocks. Capacity is 150 $\mathrm{m}^{3} \mathrm{HLW} / \mathrm{yr}$; one canister of glass $(150 \mathrm{l}, 350 \mathrm{~kg}$ ) per day. Waste canisters are stored in forced air-cooled pits in underground concrete vaults.

The AVM has been operating successfully with Marcoule UP-1 waste since June 1978. COGEMA plans to install scaled-up AVM-type plants (capacity of 50 liquid feed/hr per line vs AVM's $36 \mathrm{l} / \mathrm{hr}$ at La Hague) to treat high-level wastes from La Hague's UP-2 and UP-3 fuel reprocessing plants.

France has also sold AVM technology to other nations. Eurochemic plans to install an AVM-type plant at their WAK fuel reprocessing pilot plant at Karlsruhe and may use the AVM process at their first industrialscale reprocessing waste treatment plant; other countries are considering using the AVM process.

6. Management of non-high-level wastes:

A number of nuclear energy centers are operating waste incinerators and pilot plants for incorporating non-high-level wastes in bitumen, concrete or resins.

\section{FUEL CYCLE AND WASTE MANAGEMENT R\&D}

Research and development activities under way at France's nuclear research centers are summarized below. 


\section{Fuel Reprocessing and Plutonium Recycle}

The CEA is continuing to develop processes for recovery and recycle of plutonium from spent FBR fuels.

1. Laboratory-scale reprocessing studies (FAR)

2. Pilot plant demonstrations of FBR fuel reprocessing schemes (Marcoule)

3. Development of technology to fabricate MoX fuels for recycle to FBRs and LWRs (Cadarache).

High-Level Waste Treatment

French R\&D in HLW treatment has emphasized development of the PIVER (pot vitrification) and AVM (rotary kiln calciner and metallic melter) processes. The Marcoule staff is also currently testing a ceramic melter and actively investigating the properties of high-level waste forms.

\section{Treatment of Other Wastes}

Other waste treatment studies include:

1. partitioning of TRU wastes and measurement of TRU waste glasses (FAR)

2. meltdown of cladding residues (Marcoule)

3. volume reduction of solid wastes (Cadarache and Marcoule)

4. incorporation of non-high-level wastes, including organic liquids, in bitumen (Cadarache and Marcoule) and thermo-setting resins (Grenoble)

5. management of gaseous wastes, including work on the incorporation of ${ }^{129} \mathrm{I}$ in glasses and operation of a half-scale AVM-type plant to study vitrification plant off-gases (FAR and Grenoble).

\section{Waste Disposal}

French waste disposal R\&D is targeted to have a pilot plant repository for alpha-bearing waste operational by 1985 . Rock salt and crystalline rocks are presently being studied for geologic disposal. The reconnaissance of salt formations in France has indicated the existence of several promising areas. 
However, present plans are to devote a significantly greater effort to crystalline rocks. The possibility of disposal in granite has been evaluated for the site of La Hague, and plans are under way for a large program that will evaluate many other crystalline rock formations.

France is also contributing to seabed disposal technology through studies of deep seabed structures, marine biology, system studies and canister development.

\section{FEDERAL REPUBLIC OF GERMANY}

\section{NUCLEAR FUEL CYCLE POLICY AND PROGRAMS}

Major West German resources are being applied to the installation of LWR power stations, closure of the LWR and THTR fuel cycles and demonstration of THTR and LMFBR technology.

Adequate provision for nuclear waste management has become a precondition for issuing construction permits for additional reactors in West Germany. To satisfy this requirement, West Germany intends to build several small (400-t) reprocessing plants at various sites. The spent nuclear fuel will be stored on an interim basis prior to reprocessing either in AFR facilities or in expanded reactor pools. The nuclear waste will be disposed of at the proposed Gorleben repository. At present, the Federal Republic of Germany is considering only the salt dome repository.

\section{ORGANIZATION}

The Federal Ministry for Science and Technology (Bundesministerium für Forschung und Technologie, BMFT), located at Bonn, promotes and coordinates nuclear research and nuclear engineering in West Germany within the framework of the German nuclear program. Development of fuel cycle and waste management technology is handled primarily by the following institutes and companies: 
1. ALKEM GmbH, Hanau (MOX fuels development)

2. Deutsche Gesellschaft für Wiederaufarbeitung von Kernbrennstoffen mgB (DWK), Hannover (Germany Fuels Reprocessing Company; design, construction and operation of fuel recycle and waste treatment facilities)

3. Institut für Tieflagerung der GSF (GSF/IfT), Clausthal Zellerfeld (Underground Storage Institute, Society for Radioactive and Environmental Research; operation of the ASSE salt mine waste repository and development of geologic waste isolation technology)

4. Gesellschaft für Wiederaufarbeitung von Kernbrennstoffen mbH (GWK), Leopoldshafen (Fuel Reprocessing Company, operator of WAK reprocessing pilot plant)

5. Hahn-Meitner Institut für Kernforschung Berlin, GmbH (HMI), Berlin (fuel cycle system safety assessment; advanced waste form development)

6. Kernforschungsanlage Jülich GmbH (KFA), Jülich (Jülich Nuclear Research Center; HTGR fuel cycle development)

7. Kernforschungszentrum Karlsruhe (KfK), Karlsruhe (Karlsruhe Nuclear Research Center; LWR and FBR fuel cycle and waste management development)

8. NUKEM GmbH, Hanau (fuel cycle engineering and systems studies)

9. Physikalisch-Techn ische Bundesanstalt (PTB), Braunschweig (Federal Physical-Technical Bureau; geologic waste isolation).

Responsibility for design and construction of the Gorleben repository is divided as follows:

1. The reponsible licensing body is the Lower Saxony Ministry of Public Affairs.

2. The federal government is to build and operate the waste repository in the salt dome. This reponsibility has been assigned to PTB's Division for Storage and Final Disposal of Radioactive Wastes in Braunschweig. In this endeavor, РTB has three major partners:

- Bundesanstalt für Geowissenschaften und Rohstoffe (BGR), the West German federal geological survey 
- Entwicklungsgemeinschaft Tieflagerung (EGT), the Development Association of R\&D groups at GSF/Ift (Braunschweig) and Karlsruhe

- Deutsche Gesellschaft zum Bau und Betrieb von Endlagern für Abfalle (DBE), the German Company for Construction and Operation of Final Storage Facilities for Wastes.

BGR is investigating potential thermal, flood and other geology-related effects in the Gorleben salt repository. EGT is to see that needed R\&D for final storage at Gorleben is done. DBF has the actual repository design and construction responsibility. Activities are divided among DBE's three federally-owned founding companies as follows:

- Salzgitter $A G$-- process technology

- Saarberg Interplan GmbH -- mining activities

- Industrieverwaltungs $\mathrm{GmbH}$-- management of DBE.

PTB has also been assigned (early 1979) to handle the task of getting the Asse II repository relicensed.

COMMERCIAL NUCLEAR ACTIVITIES

1. Power production (GWe): 1980--0.05 PHWR and 8.8 LWR (13\%), 1982--0.30 THTR, 1985--0.3 LMFBR and 19.6 LWR, 2000--53 LMFBR, indefinite future-25.9 LWR.

2. Uranium mining and milling: $100 \mathrm{tU} / \mathrm{yr}$.

3. Uranium enrichment: Uranit $\mathrm{mbH}$, a partner with British and Dutch companies in the URENCO consortium, plans to build a 1000-tSWU/yr gas centrifuge plant at Gronau. Start of construction is expected in 1981.

4. Fuel reprocessing: WAK plant (DWK, Karlsruhe) is a 40-tHM/yr pilot plant, used for routine reprocessing of spent fuels and as a test facility for new processes and components. KEWA, a DWK subsidiary, is a partner with French and U.K. companies in United Reprocessors GmbH. DWK 
has signed a contract for COGEMA (France) to reprocess $1700 \mathrm{t}$ of spent fue 1 elements at La Hague to meet German needs. The recovered plutonium is to be returned to Germany.

\section{FUEL CYCLE AND WASTE MANAGEMENT R\&D}

With extensive programs to use or demonstrate three reactor systems (LWR, HTGR and LMFBR), West Germany is applying major scientific and engineering effort to the development of associated fuel cycle and waste management technology. Summaries of selected programs are provided below.

\section{Fuels Fabrication}

West Germany's primary fuel development programs are conducted by ALKEM in facilities at Hanau and by KFA at Jülich. ALKEM, with a MOX fuels pilot $\mathrm{plant}$ rated at $18 \mathrm{t} / \mathrm{yr}$, develops and demonstrates technology for fabrication of LWR and LMFBR fuels. KFA, assigned overall HTGR responsibility, develops and tests $\mathrm{ThO}_{2}-\mathrm{UO}_{2}$ fuels.

\section{Fuels Reprocessing}

Studies of LWR and LMFBR fuel reprocessing are centered at Karlsruhe where the following facilities are available:

1. KfK's Institute for Hot Chemistry has extensive hot cell facilities for reprocessing studies

2. TEKO Hall, designed for large-scale cold tests of reprocessing methods, processes and components

3. The WAK pilot plant.

Thor ium fuel reprocessing technology is the responsibility of KFA's Institute of Chemical Technology at Jülich, which has a $2-\mathrm{kg} /$ day hot reprocessing pilot plant (Jupiter) under construction. Hot operations are scheduled for 1985.

High-Level Waste Solidification

Various techniques for solidifying HLW have been explored at the Karlsruhe, Jülich and Hahn-Meitner Institutes: 
1. The VERA process (spray calciner plus metal melter) was developed and tested in nonradioactive equipment at Karlsruhe, then supplanted by a ceramic melter. KfK has also tested other solidification techniques.

2. The PAMELA process (production of phosphate glass beads with a ceramic melter and bead maker; incorporation of the beads in a metal matrix to form a "Vitromet") was developed and tested by Gelsenberg A.G. and Eurochemic.

3. The FIPS process (drum dryer and in-pot melter) was developed at Jülich to vitrify thorium fuel cycle wastes.

4. HMI has taken an active part in developing improved waste forms and glass characterization technology.

West Germany's current mainline effort on HLW solidification R\&D is to build a pilot plant at Mol and demonstrate a modified PAMELA process designed to produce either a borosilicate Vitromet or borosilicate blocks (startup -1986). Supporting ceramic melter tests are in progress at Karlsruhe and in Eurochemic facilities at Mol.

\section{Treatment of Other Wastes}

Other waste treatment studies include:

1. Partitioning and immobilization of alpha-bearing wastes; packaging and characterization of waste glasses containing alpha-emitters (Jülich).

2. Handling and packaging of cladding hulls (Karlsruhe)

- Properties of hulls (e.g., heat generation, tritium release)

- Immobilization of hulls in concrete.

3. Volume reduction of liquid wastes by evaporation and/or chemical treatment.

4. Combustion and mechanical volume reduction of solids (Jülich and Karlsruhe).

5. Incorporation in bitumen, resins or concrete -- including in situ solidification in concrete in a geologic repository (Karlsruhe). 
6. Management of airborne effluents:

- In-plant control and storage (Jülich and Karlsruhe)

- Cryogenic processes for noble gas recovery (Karlsruhe)

- Ion implantation of noble gases in a metal matrix (Karlsruhe). Waste Disposal

Since 1965, the Federal Republic of Germany's efforts to develop geologic waste disposal technology have been focused on work at the Asse salt mine. The mine has been used for large-scale experimental disposal of low- and intermediate-level wastes. R\&D activities have included development of cavern construction technology, testing of various techniques for placing waste containers in repositories, rock mechanics studies, in situ measurements of thermal and hydrologic parameters and safety analyses (GSF/Ift). KfK and GSF/Ift are cooperating in a program to develop technology for the in situ solidification (in a cement matrix) of low- and intermediate-level wastes in a shaped salt cavern. KfK is also studying radionuclide migration. West Germany also intends to convert the Konrad iron mine (at Salzgitter, $45 \mathrm{~km}$ from Asse) into an industrial repository for non-alpha-bearing wastes.

HMI has the lead in a major West Germany program ( $\$ 12$ million spread over four years) to assess the safety of the post-reactor fuel cycle, including final disposal of wastes in salt. The Gorleben salt dome repository is to have the capacity for 23,000 drums/yr of non-HLW $(10,000$ e $200 \mathrm{l} / \mathrm{drum}$ and 13,000 e $400 \ell$ /drum; $10,700200-\ell$ drums/yr of HLW; and $160070-\ell$ canisters/yr of HLW glass.)

Jülich is investigating the deep-well disposal of tritiated water and the ocean disposal of ${ }^{85} \mathrm{Kr}$ cylinders. 


\section{INDIA}

NUCLEAR FUEL CYCLE POLICY AND PROGRAMS

India is striving for complete nuclear self-sufficiency. The country started with LWRs, switched to installation of PHWRs (to avoid enrichment) and plans to convert to a ${ }^{233}$ U-Th FBR system which will allow use of India's plentiful thorium resources. Because of transportation problems, India has adopted a policy of setting up low-capacity fuel cycle complexes near major power stations, rather than establishing a centralized plant.

\section{SELECTED AGENCIES AND NUCLEAR CENTERS}

- Atomic Energy Commission, Bombay

- Bhabha Atomic Energy Centre (BARC), Trombay, Bombay

- Madras Atomic Power Project, Kalpakkam

- Tarapur Atomic Power Project, Tarapur.

\section{COMMERCIAL NUCLEAR ACTIVITIES}

1. Power production (GWe): 1980--0.4 LWR and 0.62 PHWR, 1984--1.28 LWR and PHWR, 1990--6 (7\%).

2. Uranium mining and milling: $200 \mathrm{tu} / \mathrm{yr}$.

3. Fuel reprocessing: India has installed two fuel reprocessing plants and is planning a third. They are situated in the following locations:

- Trombay (BARC): A 60-tHM/yr pilot plant for LWR fuels; Trombay produced the plutonium used in India's nuclear weapon test

- Tarapur: a 100-tHM/yr plant for LWR and PHWR (CANDU) fuels

- Madras: An "industrial"-scale plant to handle PHWR and FBR spent fuels from Madras area power stations. 
4. HLLW solidification: A waste immobilization plant is under construction at Tarapur, scheduled for startup in 1979-1980. It is based on a semicontinuous pot process developed at Trombay. The HLLW feed is preconcentrated, then calcined in the calciner-melter pot. When the pot is $75 \%$ full of calcine, the waste is melted and drained into a waste canister.

5. Non-HLW treatment: BARC has a liquid-waste treatment plant.

\section{WASTE TREATMENT R\&D}

BARC is involved with the following programs:

1. TRU waste management

- partitioning of TRU wastes

- conversion of TRU wastes into insoluble aluminosilicates by a hydrothermal process

2. Bituminization of non-high-level wastes

3. Interim storage and treatment of Zircaloy fuel hulls.

\section{WASTE DISPOSAL}

India intends to develop a repository for high-level and TRU wastes. It has conducted a geological survey for potential repository sites and has supporting R\&D under way at BARC, Trombay. Igneous rock and sedimentary formations currently show the best potential.

\section{ITALY}

\section{NUCLEAR FUEL CYCLE POLICY AND PROGRAMS}

Italy has outlined an ambitious nuclear power program including installation of many LWRS and PHWRs; participation in the Eurodif enrichment plant project in France; partnership in LMFBR demonstration plants in France and 
West Germany, hopefully leading to a domestic FBR system; and development of fuel cycle self-sufficiency. However, accomplishment of these objectives is questionable at present because of economic problems, plant siting difficulties and public opposition.

Long-term Italian policy assumes the need to recover plutonium and uranium from spent reactor fuels as well as the need for geologic disposal of conditioned high-level waste. With respect to the latter, Italy, under CEC sponsorship, is investigating the potential of clay formations for final storage.

\section{ORGANIZATION}

The Ministry of Industry has overall responsibility for nuclear energy matters with decisions subject to approval by Parliament. Other Italian organizations with major roles include:

- CNEN, National Nuclear Energy Commission

- Casaccia Nuclear Studies Center

- ENEL, the state electricity utility

- ENI, the state energy group

- AGIP Nucleare SpA.

\section{COMMERCIAL NUCLEAR ACTIVITIES}

1. Power production (GWe): 1980--0.15 GCR and 1.24 LWR, 1983--0.04 LWCHW, 1985--3.2 LWR, GCR and LWCHW, 2000--12 GCR, and indefinite future--5.1 LWR .

2. Uranium mining and milling (tU/yr): 1985--120.

3. MOX fuel fabrication: AGIP Nucleare is building a 14-t/yr plant at Rotondella to fabricate fast breeder $\mathrm{PuO}_{2} / \mathrm{NO}_{2}$ fuels for the super Phenix FBR core. Startup is scheduled for 1982. 
4. Spent fuel reprocessing: Italy has two pilot-scale reprocessing plants (see R\&D -- CNEN), and the construction of an industrial-scale plant is be ing evaluated by CNEN and AGIP Nucleare. Probable capacity is 1200 tHM/yr. The location will be near EUREX (Torino area) or ITREC (Rotondella area).

\section{FUEL CYCLE AND WASTE TREATMENT R\&D}

Work under way is summarized below.

AGIP Nucleare, Milan

1. Fuel development: MOX fuel fabrication.

2. Non-HLW treatment: Combustion of solid wastes in molten salts. CNEN, Rome

1. Fuel reprocessing: The CNEN sponsors fuel reprocessing R\&D (LWR and FBR fuels) at its Saluggia and Trisaia Centers:

- EUREX (Saluggia Center, near Torino) was initially designed for MTR fuels. EUREX now has a chop-leach head-end and capability for LWR oxide fuels. Capacity of MTR fuels is $30 \mathrm{~kg} /$ day and of LWR oxides is $50-100 \mathrm{~kg} /$ day.

- ITREC (Trisaia Center, Rotondella) was built for thorium fuel reprocessing and has a chop-leach head-end. The plant's current assignment is FBR fuel reprocessing R\&D.

2. HLW solidification: CNEN and AGIP Nucleare are collaborating on plans to build two vitrification demonstration $p l a n t s$ based on a batch process: IVET-1, a cold plant to be built at CSN-Casaccia; and IVET-2, a hot plant to be coupled with one of CNEN's small reprocessing plants. IVET-3, a cold demonstration plant for a continuous process (perhaps a French AVM $\mathrm{plant}$ ), is also under consideration.

CNS, Casaccia

1. HLW vitrification: Development continues on ESTER, a multistage pot calcination-vitrification process that may produce either a phosphate or a borosilicate glass. ESTER has been tested in hot cell runs at Ispra. 
2. Non-HLW treatment:

- immobilization in polymer impregnated cement

- characterization of waste forms.

3. TRU wastes: partitioning and transmutation.

\section{WASTE DISPOSAL}

CNEN is evaluating the argillaceous sediments near the Trisaia Center in southern Italy. Supporting R\&D includes in situ tests of thermal and radiation effects, engineering development and risk assessment. CNEN-Casaccia (Rome) and the CEC Joint Research Center at Ispra are contributing to geologic isolation safety assessments. Operations in a test repository are expected to start by the mid-1980s.

\section{JAPAN}

\section{NUCLEAR FUEL CYCLE POLICY AND PROGRAMS}

The Japanese government considers nuclear energy essential to meet anticipated energy demands. The basic strategy of nuclear power reactor development is to proceed from purchased LWR technology to domestic development of the heavy-water-moderated, boiling light-water-cooled reactor and fast breeder reactors.

Japan also feels it is necessary to reprocess spent fuel in order to make full use of the uranium and plutonium contained in the fuel. The reprocessing plant owner will be responsible for treatment of the high-level waste produced. Japan is presently planning to vitrify high-level liquid waste after it has cooled five years. The solidification process under consideration mainly comprises (1) pretreating the HLLW through a fluidized bed calciner or by wet denitrator mixing with formic acid, (2) melting the borosilicate glass in a Joule heated ceramic melter or in a direct high frequency induction melter, and (3) casting the glass into a stainless steel canister. 
The government will be in charge of the isolation of high-level solidified waste with the cost of the isolation supported by the waste originator. Solidified HLW will probably be stored in engineered storage facilities for 50-100 years. Disposal options for solidified HLW include geologic and seabed isolation and transmutation. The present research study is in the early stage of selection of potential geological formations with the following formations under consideration: granite rocks, diabase, shale, zeolite tuffs and limestone.

Disposal of low-level solid waste is expected to be accomplished by both sea dumping and land isolation. Lower activity and non-transuranic wastes would be dumped into deep ocean after immobilization in stable forms such as cement, concrete or bitumen. Higher level wastes and those unsuitable for ocean dumping would be isolated on land, probably in an engineering storage facility.

\section{ORGANIZATION}

The Japan Atomic Energy Commission (JAEC) is one of the advisory organizations for the Prime Minister. It was established for the purpose of implementing the national policy on nuclear energy research, development and utilization. The Nuclear Safety Commission was established in 1978 and is responsible for regulatory aspects of the nuclear industry, especially with regard to safety. The Science and Technology Agency (STA) was established for the purpose of general administration and the promotion of research and development. Under the supervision of STA are the Japan Atomic Energy Research Institute (JAERI) and the Power Reactor and Nuclear Fue 1 Development Corporation (PNC). The Ministry of International Trade and Industry (MITI) takes charge of matters related to nuclear power generation and supervises the Nuclear Fuel Research Committee and the Radioactive Waste Management Center.

Other organizations and agencies of importance in nuclear research and deve lopment include: 
- Central Research Institute of Electric Power Industry (CRIEPI)

- FBR Engineering office (FBEO)

- Tokyo Institute of Technology

- Nuclear Fuel Service Company

- Government Industrial Research Institute, Osaka (GIRIO)

- Mitsubishi Atomic Power Industries, Inc.

\section{COMMERCIAL NUCLEAR ACTIVITIES}

1. Power production (GWe): 1980--14.2 LWR, 0.2 LWCHW and 0.16 GCR; 1985--0.3 LMFBR and 19.8 LWR; 1990--60; 1996--80 GCR; 2000--100-150.

2. Uranium mining and milling (tU/yr): 30 .

3. Uranium enrichment: Initial stage of a gas centrifuge plant (1000 machines) has begun operation at the Ningyo Pass mine site. Fu11 operation (75 tSWU) with 7000 machines is scheduled for 1981.

4. MOX fuels: Japan relies on private industry to fabricate uranium fuels and on PNC for development and fabrication of MOX fuels. PNC'S Plutonium Fuel Fabrication Facility (PFFF) has two fabrication lines -- an FBR fuel line with a capacity of $15 \mathrm{~kg}$ MOX/day, and a HWR fuel line with a $50 \mathrm{~kg}$ MOX/day capacity.

5. Fuel reprocessing: Japan has contracts in place with COGEMA (France) and BNFL (UK) to provide fuel reprocessing service until Japan's domestic plants can carry the load. Japanese facilities and activities include:

- Tokai Mura plant (PNC), a 210-tHM/yr Purex plant for LWR oxide fuels which started operations in late 1977. The process includes a chop-leach head-end and a mixer-settler solvent extraction system.

- Plans for an industrial two-line, 6-tU/day reprocessing plant, which may be built and operated by private industry.

6. HLW solidification: Japan's stated intent is to have a demonstration vitrification plant operating by 1987 to support the Tokai Mura reprocessing plant. PNC, Japan's fuel cycle company, is considering several types 
of technology: fluid-bed calcination, followed by sintering, melting or hot-pressing; and the ceramic melter. Support R\&D is being done by PNC and JAERI.

7. Non-HLW Management: JAERI has a $30-l / h r$ bituminization plant at Oarai, and PNC plans to build a similar 200- $/ \mathrm{hr}$ plant. Combustible solids incinerators are in service at Tokai and Oarai.

\section{FUEL CYCLE AND WASTE MANAGEMENT R\&D}

\section{Uranium Enrichment}

Research and development efforts include gas centrifuge technology and gaseous diffusion and ion exchange chromatography (JAERI).

\section{Fuel Fabrication}

Fabrication technology for LWR, HWR and FBR fuels as well as coatedparticle $\left(\mathrm{UO}_{2}\right)$ fuels for JAERI's experimental HTR are under development at PNC.

\section{Fuel Reprocessing}

PNC is building three research facilities for FBR fuels at the Tokai Works:

- Technological Test Facility for the purpose of cold engineering tests. Construction completion is scheduled for 1982.

- Chemical Processing Research Facility will test hot operations at a capacity of $1 \mathrm{~kg} / \mathrm{batch}$. Cold test runs are expected in 1980 with hot equipment tests scheduled for 1982.

- Reprocessing Research Facility will be a 150-kg/day hot engineering facility. Installation will be completed in 1987.

Present PNC R\&D activities include equipment development, process studies and airborne effluent control systems development. 


\section{HLW Solidification}

- One of the solidification processes will be chosen during 1981, and further engineering and mockup tests will be performed for this process. Radioactive tests will begin in the hot cells in 1981; operation of the solidification pilot plant is scheduled for 1987.

PNC is investigating fluidized bed calcination of high-sodium HLLW followed by conversion to glass or ceramic. Development of a rising-level pot melter for FBR wastes is also under way. PNC is continuing work on a three-year (1978-81) program on a Joule heated ceramic melter and an integrated calciner melter system with a $250-\mathrm{kg} /$ day capacity.

JAERI is investigating rotary kiln calcination and vitrification of wasteloaded zeolite ion exchangers, while GIRIO is studying sintering or hotpressing of calcined wastes and devitrification of waste glasses.

Non-HLW Solidification

JAERI is studying immobilization in bitumen and polyethylene and the use of plastic impregnated concrete containers.

TRU Wastes

Incineration and acid digestion of combustibles and TRU waste partitioning are under investigation at PNC and JAERI, respectively.

\section{Gaseous Wastes}

By 1982 the Tokai Mura reprocessing plant is to be equipped with a cryogen ic plant for ${ }^{85} \mathrm{Kr}$ recovery. The Tokyo Institute of Technology is developing a method for $\mathrm{Kr}$-Ar separation by thermal diffusion.

Packaging and Transportation

Several agencies, working under STA sponsorship, are studying the effects on waste and spent fuel packages of drop impact, fire and immersion in deep water. 
$\underline{D \& D}$

The Japanese utilities have started on a major reactor D\&D study and are spurring the development of a furnace facility to convert noncombustible wastes to ingots and ceramic blocks.

\section{WASTE DISPOSAL}

Japan plans to have a licensed, industrial-scale repository for high-level and TRU wastes ready for operation by the year 2000; solidification and storage demonstration tests are scheduled to be completed in about 10 years, and geologic disposal demonstration tests will be started in about 1985.

PNC is looking for possible sites for geologic isolation. Granite, basalt, zeolitic tuff, shale and diabase are identified as possible host rocks. Other options under investigation are seabed disposal and transmutation. A survey by Mitsubishi Metals identified granite and zeolite rock formations as potential sites and suggested further consideration be given to limestone, diatomite and shale formations.

In further work, PNC is to conduct physical and chemical tests on different rocks; JAERI is to conduct the safety studies, and the Atomic Energy Bureau is to develop the disposal system.

\section{MEXICO}

\section{NUCLEAR FUEL CYCLE POLICY AND PROGRAMS}

Mexico plans major nuclear power capability. The emphasis to date is on installation of power stations and exploration of what may be extensive uranium resources. The country also plans to develop fuel cycle technical capability, with construction of pilot and laboratory facilities. 
SELECTED AGENCIES AND RESEARCH CENTERS

- Instituto Nacional de Energia Nuclear, Mexico City (National Nuclear Energy Institute)

\section{COMMERCIAL NUCLEAR ACTIVITIES}

1. Power production (GWe): 1983--1.31 LWR, 1999--6.7.

2. Uranium mining and milling (tU/yr): 1978--20, 1985--550.

\section{FUEL CYCLE R\&D}

National Nuclear Energy Institute

- Fuel reprocessing pilot plant

- MOX fuel fabrication.

\section{NETHERLANDS}

\section{NUCLEAR FUEL CYCLE POLICY AND PROGRAMS}

In 1975 the Dutch government approved plans for three new 1000-MWe nuclear facilities and expansion of the Almelo uranium enrichment plant to $1250 \mathrm{tSWU} / \mathrm{yr}$. However, subsequent government changes and adverse public op inion have repeatedly delayed furtherance of these plans. The latest government has called for resolution of waste management questions before deciding on further nuclear power plants. To this end, it initiated a study of waste disposal sites, and in 1979 submitted a report to Parliament which indicated that radioactive waste can be stored safely in underground salt domes in state-owned property in the northeastern region of the country. In the meantime, the government also plans a two-year information campaign on energy policy in general in order to gauge public feeling before making any decisions about nuclear power. 
In spite of this, the nation is continuing to conduct LWR, FBR, homogeneous reactor, and fusion R\&D, and supports CEC reactor development programs.

\section{ORGANIZATION}

The Ministry of Economic Affairs has overall responsibility for nuclear energy matters; the decisions are subject to approval by Parliament. Other organizations with major roles include:

- KEMA, the laboratories of the joint electric utilities at Arnhem

- Energieonderzoek Centrum Nederland (ECN) which provides numerous services relating to operation of the Dutch nuclear power plants such as radwaste handling, radiation dosimetry and training of personnel.

- Foundation for Fundamental Research of Matter (FOM), Institute of Plasma Physics at Nieuwege in

- Neratoom, an organization of three Dutch companies, which coordinates research, development, engineering and marketing of components for nuclear reactor installations

- Organization for Applied Scientific Research and Development (TNO) which researches materials analys is, crack propagation, embrittlement, radiation protection and sodium technology

\section{COMMERCIAL NUCLEAR ACTIVITIES}

1. Power production (GWe): 1980--0.49 LWR, long-term--3.5.

2. Uranium enrichment (tSWU): 1978--200, future--1250.

\section{FAST BREEDER REACTOR}

A Belgian/Dutch/German industrial consortium, SNR, was formed in 1968 to design and build the prototype sodium-cooled, fast breeder SNR-300 at Kalkar, West Germany. Construction of this facility is under way. 


\section{FUEL CYCLE AND WASTE MANAGEMENT R\&D}

KEMA has undertaken a new project to define the techniques and facilities needed by the Dutch nuclear power stations to treat and store their own nuclear wastes. A major area of concern is the volume reduction of solid contaminated wastes. They are considering incineration but find it difficult to buy the sma11-capacity equipment required. They are also looking at other techniques such as HEDL's acid digestion method.

\section{Waste Isolation}

The Netherlands has an active geologic waste isolation R\&D program under way concentrating almost exclusively on salt dome repositories. The government presently plans to drill six holes, $\sim 500 \mathrm{~m}$ in depth, on state-owned property. Two salt domes will be examined.

Dutch investigators have adopted preliminary parameters for the conceptual design of a repository:

- 50- $\ell$ canisters of solidified HLW, $2 \mathrm{~m}$ long with a linear heat rate of $300 \mathrm{~W} / \mathrm{m}$

- disposal areas at depths of 600,750 and $900 \mathrm{~m}$

- a generalized maximum temperature of $60^{\circ} \mathrm{C}$, with disposal areas at temperatures as high as $100^{\circ} \mathrm{C}$ and local areas around the boreholes at $250^{\circ} \mathrm{C}$

- spacing around each waste canister of $30-35 \mathrm{~m}$

- a repository volume adequate for 50,000 canisters

- a surface facility for preliminary storage (up to 30 years) of HLW canisters

- bulk disposal cavities for low-level waste (2000-5000 $\left.\mathrm{m}^{3} / \mathrm{yr}\right)$.

Despite the salt dome studies, the Dutch believe they will have to go to surface storage by the 1990s as an interim solution to radioactive waste disposal. They plan to cooperate with the U.S., Japan, Britain and France in investigating possible burial of wastes in salt formations under the ocean and in the continental shelf. 
The Dutch, with CEC financial support, are also working in several areas of geologic isolation technology:

- theoretical studies of thermal effects in salt dome repositories

- measurement of distribution coefficients of various radionuclides in various soil samples

- hydrogeologic evaluations

- safety assessment.

A conceptual study has shown that waste equivalent to the amount produced by a 25,000-MWe nuclear capacity installed over a period of 40 years could be stored underground in a saline dome.

Calculations show that erosion by the aquifers surrounding the saline dome would result in the saline environment of the waste repository (assumed to be about $200 \mathrm{~m}$ of salt all around the repository) being leached away after approximately one and one-half million years.

\section{SPAIN}

\section{NUCLEAR FUEL CYCLE POLICY AND PROGRAMS}

Spain has long planned for extensive nuclear power, but in recent years has been forced to significantly reduce forecasts of capacity. Present emphasis is on LWR construction. The country is attempting to develop complete fuel cycle self-sufficiency with an interest in Eurodif (uranium enrichment) and plans to develop fuel fabrication, fuel reprocessing and waste management capability.

\section{SELECTED AGENCIES AND RESEARCH CENTERS}

- Centro de Energia Nuclear de Soria, Soria (about 110 miles from Madrid (Soria Nuclear Energy Center)

- Centro Nacional de Energia Nuclear Juan Vigon, Madrid (Juan Vigon National' Nuclear Energy Center) 
- Empresa Nacional del Uranio SA (ENUSA), Madrid (National Uranium Company)

- Junta de Energia Nuclear (JEN), Madrid (Atomic Energy Commission).

COMMERCIAL NUCLEAR ACTIVITIES

1. Power production (GWe): 1980--0.48 GCR and 1.52 LWR, 1987--10.9 LWR $(60 \%)$, and indefinite future--12.8.

2. Uranium mining and milling (tU/yr): 1978--190, 1985--1270.

FUEL CYCLE AND WASTE TREATMENT R\&D

Juan Vigon

1. Fue 1 development.

2. Fuel reprocessing: JEN operated a small pilot plant at the Juan Vigon Center a few years ago and plans to build a 2-t/yr pilot plant at the new Sor ia Nuc lear Energy Center.

3. HLW solidification: The Juan Vigon Center has done limited laboratoryscale R\&D on a variety of techniques for high-level waste solidification.

4. Non-HLW treatment:

- decontamination of liquid wastes

- immobilization in asphalt or cement.

\section{WASTE ISOLATION}

Spain would like to commission a repository for high-level and other wastes and plans to start up a pilot repository by the late 1980s. For several years Spain has stored non-HLW drums in an abandoned iron mine located in the Sierra Morena. A search is being made for other repository sites and supporting R\&D is in progress. 


\section{SWEDEN}

NUCLEAR FUEL CYCLE POLICY AND PROGRAMS

With a lack of coal and oil resources, Sweden embarked on a major nuclear power program during the 1950s with emphasis on LWRs. In 1977, public opposition and a new government produced a law which required a reactor operator, before any new reactor can be fueled, to provide assurance that the spent fuel can be reprocessed and the waste can be stored safely, or prove that safe terminal storage of spent fuel can be affected. Since the "Stipulation Law" went into effect, the following significant events have occurred:

- December 1977

KBS' first report was published which dealt with the chain that ends with final storage of vitrified high-level reprocessing waste. This report and a reprocessing contract between the utilities and the French company, COGEMA, were used as support for applications for permission to fue 1 two reactors, Ringhals 3 and Forsmark 1 .

- January-August 1978

The KBS report was circulated to 24 Swedish and 23 foreign agencies for review.

- October 1978

After extensive evaluation and painful internal negotiations, the government, rejected the applications. The government, however, gave its approval to the technology and methods proposed by KBS. The reprocessing contract with COGEMA was also found acceptable. But, in one respect the evidence was found to be insufficient; it was not shown that there was a rock mass with the properties required in the KBS safety analysis that is large enough to host a repository. After this decision the three-party government resigned because of disagreement on the nuclear program and was followed by a minority based government of liberals. 
- October 1978-February 1979

KBS made supplementary core drillings in two of the three areas which had been investigated earlier. Based on the broader data base thus received, new applications for loading the two reactors were submitted to the government.

- February-March 1979

The results of the supplementary geological investigations were reviewed by the Swedish Nuclear Power Inspectorate. To strengthen the geological competence with in the Inspectorate, they consulted a group of geologists. The majority of this group concluded that there still was insufficient data to prove that there was a large enough rock formation in Sweden to host a repository. The criticism expressed by the group majority was, however, effectively rebutted by KBS and competent geologists outside KBS. Thus the Inspectorate, in spite of the evaluations by the majority of the ir consultants, recommended that the government approve the applications.

- June 1979

The government approved the applications. The approval concluded with instructions to reactor owners to continue the work on high-level waste management.

Since May of 1979, most decisions on nuclear policy have been postponed pending a referendum scheduled for March 1980. At least two questions for the referendum have been agreed upon. Do voters want a total of no more than 12 reactors built and started up? Do they want no additional reactors started and the six currently operating reactors phased out over a 10-year period?

At the present time, all the necessary permits have been issued to start up the reactors in question. However, another law has been passed which is called "the-time-for-consideration-law." This states that no new reactor may be charged with fuel before July 1, 1980, thereby allowing for the March 1980 referendum. 


\section{ORGANIZATION}

The nuclear fuel cycle and waste management are the responsibility of the Department of Industry (Energy), with the following organizations having major roles.

1. Swedish Nuclear Fuel Supply Company (SKBF) is controlled equally by the private utilities and the State Power Board. SKBF is responsible for providing nuclear fuel, reprocessing services, etc., for the Swedish power companies. SKBF established the Nuclear Fuel Safety Project (KBS) to implement requirements of the 1977 "Stipulation Law."

2. Program Council for Radioactive Waste (PRAV) is responsible for reactor waste, AFR storage, reprocessing and geologic disposal, and sponsors R\&D in these areas.

3. Studsvik/Energiteknik $A B$ is a state-owned nuclear energy corporation. The company is the central institution for Swedish applied atomic research work.

4. ASEA-ATOM $A B$ is a joint venture by the Swedish government and the ASEA industrial group whose major concern is design and construction of nuclear power plants.

5. The Stripa test station is located at a depleted iron mine which is owned and maintained by Stallbersbolagen, a Swedish company.

\section{COMMERCIAL NUCLEAR ACTIVITIES}

1. Power production (GWe): 1980--7.3 LWR, 1985--9.4.

2. Uranium mining and milling: potential--1500 tU/yr.

3. Fuel reprocessing: SKBF has signed a contract with COGEMA (France) for French reprocessing of Swedish fuels.

\section{WASTE MANAGEMENT R\&D}

Types of research and development work under way in Sweden are listed below: 
1. High-level wastes -- the present Swedish plan calls for overpacking waste glass canisters (prepared by France at La Hague) in stainless steel and either copper or lead and titanium cans. As a backup, a Royal Institute of Technology team is studying a concept, similar to the Sandia process, for absorbing fission products on an inorganic ion exchange material and then using the ASEA-ATOM hot isostatic pressing (HIP) method to embed the saturated ion exchanger in a stable aluminum oxide matrix. The HIP technique can also be used to encapsulate spent fuel rods or solid wastes in thick-walled aluminum oxide cylinders which are highly resistant to chemical attack. The encapsulation process has been tested with spent fuel rods.

2. Canister development for storage of spent fuels and leaching of $\mathrm{UO}_{2}$ from failed spent fuels (Studsvik).

3. Partitioning of TRU wastes (Chalmers University).

4. Combustion of solid wastes (Studsvik).

5. Waste form characterization:

- leach rates in ground water for spent fuels

- leach rates for HLW waste forms.

WASTE DISPOSAL

In 1978 KBS issued a report recommending the following HLLW management scheme:

- interim storage of spent fuels in a central storage facility

- reprocessing at La Hague in France and return of vitrified wastes to Sweden

- thirty-year storage in air, in an underground rock formation

- application of a lead plus titanium overpack and emplacement in granite formations $500 \mathrm{~m}$ underground. 
The proposal has been evaluated extensively and accepted by the Swedish government as adequate to satisfy the law and permit fuel loading in new reactors. Extensive work is continuing to qualify a repository site and to complete the development of needed technology.

For the present the plans of the nuclear utilities are based on continued work through the KBS project and other organizations. The main tasks scheduled for the near future are:

1. Design and construct a central AFR facility for Sweden. The storage pools are located underground and will have room for $3000 t$ of spent fuel in a first stage. The facility is scheduled to receive fuel in early 1985. A construction permit was received from the government in August 1979. As the capacity and detailed design of the facility may depend on the result of the referendum, however, the construction work may not be started before May 1980.

2. Organize a transportation system including a special vessel and transport casks for spent fuel. The system is scheduled to be functional in the first half of 1982 .

3. Continue work on radioactive waste disposal including the following main points:

- field studies of ground water movements and chemistry including age determination and tracer tests in areas earlier investigated by deep core drillings

- improvement of hydrogeologic instrumentation

- theoretical studies and improvement of analytical models for ground water movements

- improved models for migration of radioactive substances in fissured crystalline rock

- laboratory studies of the behavior of the back-fill material. 
$\underline{R \& D}$

- Stripa Test Station (KBS): shafts and tunnels in an exhausted iron mine at Stripa have been used to demonstrate mining techniques and to study parameters such as rock permeability, hydrologic and mechanical properties and thermal effects. The U.S. has participated in some of these tests. A new cooperative test program coordinated by the NEA and co-sponsored by Canada, Sweden, Switzerland and the U.S., is to start during the summer of 1980 .

- Studsvik Energy Center: in situ radionuclide migration.

- Chalmers University: nuclide transport by ground water.

\section{SWITZERLAND}

NUCLEAR FUEL CYCLE POLICY AND PROGRAMS

Switzerland's plans for a strong nuclear power system have run into extensive public opposition but were sustained in a referendum held in February 1979. By subsequent governmental actions, authorization was granted to proceed with preparatory measures for constructing a radioactive waste repository, and the requirement was established that producers of radioactive wastes guarantee safe and final elimination of the wastes. If the nuclear utilities do not provide this guarantee by 1985 , operating permits for five nuclear power plants, which by then will be producing almost half of the country's electric power, will be withdrawn. Swiss plans are to have spent fuels reprocessed at the La Hague plant (France), take back the HLW glass, and develop a HLW repository, probably in a deep granite formation.

\section{SELECTED AGENCIES AND RESEARCH CENTERS}

- Société Coopérative Nationale pour l'Entreposage de Déchets radioactifs (CEDRA), Baden (National Cooperative Association for the Storage of Radioactive Wastes).

- Eidg. Institut für Reaktorforschung (EIR), Würenlingen (Federal Institute for Reactor Research). 
COMMERCIAL NUCLEAR ACTIVITIES

Power production (GWe): 1980--1.94 LWR, 1987--3.8 LWR, and indefinite future--4.9 LWR.

WASTE DISPOSAL

Switzerland's objective is to evaluate the feasibility of a waste repository in Switzerland. CEDRA, the national cooperative formed to provide for waste disposal, has embarked on a repository development program estimated at more than $\$ 125$ million over the next four or five years. Major emphas is is being placed on evaluation of granite formations in the cantons of Aargau, Solothurn, Zurich and Schaffhausen. The program includes exploratory drilling at a dozen or more sites, basic R\&D and the evaluation of a site at Grims 1, in the Oberhasli region, for use as an underground laboratory for nonradioactive tests. Test drillings at the Grimsl site, starting from an existing mine access gallery, are planned for early 1980. If the project proceeds, operation of the laboratory is planned to start in 1982 with the following types of tests:

1. Measurement of rock thermal conductivities, permeabilities and ability to retain substances dissolved in the ground water

2. Evaluation of storage techniques for HLW and spent fuel casks

3. Barrier materials characteristics.

CEDRA also plans to participate in future cooperative tests in the Stripa mine in Sweden.

\section{UNITED KINGDOM}

NUCLEAR FUEL CYCLE POLICY AND PROGRAMS

The United Kingdom nuclear power program is based upon 1) a first generation of gas-cooled, graphite-moderated reactors (Magnox-clad, natural uranium metal fuels); 2) a second generation of advanced gas-cooled reactors (AGR: 
SS-clad $\mathrm{UO}_{2}$ fuels); 3) a third generation of power reactors which might be LWRs or AGRs; 4) development and demonstration of FBRs; 5) development of comprehensive fuel cycle and waste management capability for all domestic reactor systems; and 6) provision of fuel cycle services to foreign customers.

Past United Kingdom waste management practices have included:

1. closely monitored storage of concentrated HLLW in the acid form in small stainless steel tanks at the site where the wastes are generated

2. underwater storage of magnesium alloy cladding from Magnox reactor fuels

3. incineration of solid combustible wastes

4. release of low-level effluents from Windscale through a two-mile pipeline into the Irish Sea (medium-level wastes are stored for about 10 years for decay of short-lived isotopes before sea disposal)

5. burial of low-level solid wastes in trenches

6. discharge of tritium from the reprocessing sites--partly as vapor in the gaseous effluent, but mainly as tritiated water in the low-level liquid waste discharged to sea.

Short-term management $\mathrm{plans}$ for the future are as follows:

1. Until a safe and acceptable method for ultimate disposal has been developed, all radioactive wastes are to be stored in engineered repositories at or near the surface in such a manner that they can be retrieved.

2. Concentrated HLLW will continue to be stored in stainless steel tanks until a solidification plant is operational.

3. Development and demonstration of the HARVEST vitrification process is to continue with the objective of operating a fully active prototype vitrification plant at Windscale in the late 1980s.

4. HLLW glass canisters will probably be given interim storage in a water basin until ultimate disposal modes are selected and facilities provided.

5. Major studies will be made of geologic and deep ocean disposal of vitrified HLLW. 
6. Iodine removal facilities are included in plans for the new reprocessing plant to be constructed at Windscale. A removal process for ${ }^{85} \mathrm{Kr}$ may be required.

7. A waste solidification plant is to be built at Dounreay to handle highlevel waste from reprocessing PFR fuels.

ORGANIZATION

Fuel cycle and waste management responsibilities in the United Kingdom are assigned as follows:

1. The United Kingdom Atomic Energy Authority (UKAEA), an agency of the Department of Energy, sponsors and administers reactor, fuel cycle and waste management R\&D. Major laboratories include:

- Atomic Energy Research Establishment (AERE), Harwe11 (nuclear power research, fuel reprocessing and waste management $R \& D$ )

- Culham Laboratory, Culham (nuclear fusion and plasma R\&D)

- Atomic Energy Estab7ishment, Winfrith (thermal and fast reactor research)

- Dounreay Experimental Reactor Establishment (DERE) (fast reactor and fast reactor fuel cycle development)

- Reactor Fuel Element Laboratories, Springfields (development of fuels and fuel element components, waste vitrification process development)

- Risley Engineering and Materials Laboratory, Risley (reactor component development)

- Reactor Development Laboratory, Windscale (development of plutonium fuels for fast reactors and AGR R\&D)

- National Radiological Protection Board (NRPB), Harwell.

2. British Nuclear Fuels Limited (BNFL) is a UKAEA subsidiary formed in 1971 to take over all the nuclear fuel business of the former UKAEA production 
group. BNFL handles commercial fuel fabrication, fuel reprocessing (domestic and foreign), and waste treatment and has major facilities at Risley, Windscale (reprocessing) and Capenhurst (enrichment).

3. Nuclear Waste Management Division, Department of the Environment, has had the authority for regulating control of waste management since 1977, and responsibility for waste management R\&D was assigned to it in 1979.

\section{COMMERCIAL NUCLEAR ACTIVITIES}

1. Power production (GWe): 1980--0.09 HWLWR, 0.25 LMFBR and 8.3 GCR and AGR; 1982--11.4 GCR and AGR; 2000--25 to 40 (up to $75 \%$ ).

2. Uranium enrichment: BNFL has a 500-tSWU/yr gaseous diffusion plant at Capenhurst and a Urenco gas centrifuge plant. Expansion of the Urenco facility from its present $200 \mathrm{tSWU} / \mathrm{yr}$ to $400-600 \mathrm{tSWU} / \mathrm{yr}$ is planned.

3. MoX fuels fabrication (BNFL-Windscale):

- a 5- to 10-tHM/yr plant in operation

- a 1-thM/yr pilot plant for FBR fuels production in operation

- a 20-tHM/yr plant; startup is scheduled for 1984

- a 50-thM/yr plant; startup is scheduled for 1987.

4. Spent fuels reprocessing:

- Windscale (BNFL, Seascale): A 2000-tHM/yr Purex-type plant which is used for Magnox (natural uranium metal) fuels from U.K.'s gas-cooled reactors. A 400-t/yr chop-leach head-end for LWR oxide fuels was added in 1969 and operated until 1973. Revision of the oxide head-end is planned, with startup scheduled for 1981. The main role of the oxide head-end will be to test new processes for THORP.

- Thermal 0xide Reprocessing Plant (THORP, BNFL): A new plant to be built at Windscale which reprocesses LWR oxide fuels for domestic and foreign customers. A nominal capacity of 1200 tHM/yr is expected with startup scheduled for 1987. 
- A cold pilot plant (BNFL): This is being installed to test equipment and train operators for THORP. Nominal capacity is $1200 \mathrm{t} / \mathrm{yr}$. Startup was scheduled for 1979.

- PFR Reprocessing Plant (DERE, Dounreay): The Dounreay plant, with a capacity of 9-10 t/yr, was installed to treat spent fuels from the Dounreay fast reactors. After a number of years' service, it was decontaminated, remodeled and now reprocesses spent fuels from the Dounreay 250-MW PFR.

5. HLW solidification:

- HARVEST Demonstration Plant: The HARVEST process uses rjsing-level in-pot calcination and melting to produce a borosilicate glass. The hot demonstration plant is to be built at Windscale to treat reprocessing HLW. Completion date is expected to be 1987 .

- DERE Waste Vitrification Plant: The UKAEA plans to build a plant at Dounreay to treat HLW from the FBR fuels reprocessing plant. Capacity is expected to be $30 \mathrm{l} / \mathrm{hr}$ feed, with startup scheduled for the late 1980s.

\section{FUEL CYCLE AND WASTE TREATMENT R\&D}

Research and development activities under way at U.K. nuclear research centers are listed below.

\section{UKAEA-Harwe 11}

1. HLW solidification:

- process development -- FINGAL/HARVEST process (rising-level, in-pot calciner/melter, the Harwell pilot plant has a capacity of $240 \mathrm{~kg}$ glass per run.)

- ceramic melter studies

- waste form characterization.

- immobilization of fission products on $\mathrm{TiO}_{2}$. 


\section{Other wastes:}

- treatment of spent solvent

- combustion of solid wastes (pyrolysis, acid digestion and incineration )

- TRU wastes treatment and partitioning

- immobilization of cladding hulls

- control and storage of volatile radionuclides, including ${ }^{85} \mathrm{Kr}$ implantation in metal matrices

- fixation of nuclides in inorganic ion exchangers, cement or ceramic grouts, and cement-clay briquettes.

BNFL-Windscale

1. HLW solidification: The present effort is directed mainly to construction and startup of the following Windscale test and demonstration facilities:

- A hot (radioactive) pilot plant. Capacity--1l/hr feed; one waste canister per month. Scheduled to start up in 1978.

- HARVEST prototype. A full-scale mockup, built for cold demonstration of operations and equipment. Scheduled completion date is 1980 .

- HARVEST demonstration plant.

Windscale is also involved in process development and waste form characterization studies.

2. Other wastes:

- treatment of cladding hulls

- combustion of solid wastes

- effluents control.

3. Storage and encapsulation of spent fuels. 


\section{DERE-Dounreay}

Fuels reprocessing:

- use of lasers to cut fuel assembly sheaths

- solvent extraction systems

- construction of mini-pilot FRP (pulse columns). Startup is scheduled for 1980-81.

Springfields

Immobilization of HLW: al ternative waste forms.

Risley

Design of shipping casks and ships for spent LMFBR fuels.

WASTE DISPOSAL

The United Kingdom wants to provide a waste repository for high-level and alpha-bearing wastes. Options include land, seabed, and sub-seabed disposal. Milestones include selecting the site for a repository -- 1984, starting a pilot disposal operation with radioactive glass -- 1992, and operation of the repository -- 2000. Project participants include the Department of the Environment (in charge, R\&D), Institute of Geologic Sciences, and AERE-Harwe 11 (supporting R\&D).

A number of sites (crystalline rock, argillaceous and evaporite formations) have been selected for exploratory drilling and in situ investigations, and a conceptual design for a repository in hard rock has been prepared. The preferred sites will be selected in 1984, at which time a decision between seabed and deep geological disposal alternatives will be made.

The U.K. is using a systems approach and the multiple barrier concept for isolation of the waste. They are considering containers with a life of 1000 years as engineered barriers and allowing substantial reduction in radioactive levels by interim storage prior to final disposal. 
$\underline{R \& D}$

- Installation of a high-pressure/high-temperature geochemical laboratory. Startup was February 1979

- Migration of radionuclides and pathway analys is

- Thermal properties and effects (including heater tests in a granite formation)

- Properties of granite

- Seabed studies.

\section{UNION OF SOVIET SOCIALIST REPUBLICS}

\section{NUCLEAR FUEL CYCLE POLICY AND PROGRAMS}

The Soviet Union had planned to accelerate the development of nuclear power in order to reach a production goal of 15,000 MWe in 1980 and several times that amount by 1985 . However, the ir nuclear power program has fallen behind schedule, and it now appears that they may not achieve even one-half that amount. Emphasis is being placed on the following objectives.

- During the next five-year plan period (1981-85), 2400 MN RBMK units will see construction starts. These are a pressure-tube reactor which uses enriched uranium, boiling light water as a coolant and a graphite moderator.

- Completion of the "Atommash" facility for the production of standardized heavy reactor components including 1000-MW PWR vessels. This facility is now nearly two years behind schedule. Atommash is expected to produce one reactor (with components produced at another plant) in 1982 and none in 1983.

- Continued research on high temperature gas-cooled reactors for various heat-consuming industrial processes and for gas-cooled fast breeder reactors. 
- Fabrication improvements in various types of fuel elements and selection of the correct fuel for each reactor type.

- Shortening lead time on erection of nuclear power plants.

Soviet policy includes reprocessing of spent fuels from their own reactors and from those supplied to other countries. Commercial reprocessing capability will be reached in the 1980 s.

\section{ORGANIZATION}

The ultimate decisions for Soviet development are made by the Communist Party hierarchy and the Supreme Soviet. However, the overall responsibility for nuclear development belongs to the State Committee for the Utilization of Atomic Energy and the Ministry of Energy and Electrification.

Other agencies and research centers of major importance to the nuclear industry include:

- Soviet Academy of Sciences, Moscow

- V. I. Lenin Institute for Reactor R\&D, Dimitrovgrad

- V. G. Khlopin Radium Institute, Leningrad

- I. V. Kurchatov Institute for Nuclear Energy, Moscow

- Chemical Plant Research Institute, Sverdlovsk.

\section{COMMERCIAL NUCLEAR ACTIVITIES}

1. Power production (GWe): 1980--0.95 LMFBR, 9.9 LGR and 6.9 LWR; 1981--10.9 LGR; 1982--8.9 LWR; indefinite future--14.9 LGR.

2. Uranium enrichment: $7-10 \mathrm{tSWU} / \mathrm{yr}$.

3. Fuel reprocessing: The USSR is reportedly building a commercial-scale (5-t/d) plant.

\section{FUEL CYCLE AND WASTE MANAGEMENT R\&D}

Research and development activities under way in the Soviet Union are summarized below. 
Spent Fuel Reprocessing

A 3-kgU/day pilot plant has operated at the Khlopin Radium Institute since 1973.

HLW Solidification

Two nonradioactive waste vitrification pilot plants have been developed -the KS-KT-100 plant, which uses a two-stage process (fluid bed calcination followed by melting in a concrete-refractory storage pot); and a single-stage continuous process using a two-zone melter. Capacities of the KS-KT-100 and the melter are $20 \mathrm{~kg} / \mathrm{hr}$ glass and $100 \mathrm{hr}$ HLLW feed, respectively. The products are phosphate glasses. Other high-level waste forms are also being evaluated.

\section{Treatment of Other Wastes}

Two methods for treating spent fuel cladding, thermal decladding and meltdown of hulls, are under development. Efforts are being made to discover improved methods of partitioning TRU wastes. Presently, non-HLW wastes are treated in a variety of manners including chemical treatment, combustion or bituminization.

USSR laboratories are also developing processes for handling off-gases and storing ${ }^{85} \mathrm{Kr}$.

\section{WASTE DISPOSAL}

For a number of years, the Soviet Union has practiced disposal of non-HLW by injection of liquids into deep, porous strata. The nation is also evaluating geologic disposal of solid wastes in salt, granite and sandstone formations. Activities include criteria development, repository design and engineering, testing of prototypes and studies of bulk rock behavior. 


\section{INTERNATIONAL ATOMIC ENERGY ASSOCIATION (IAEA)}

The IAEA, an independent international organization belonging to the United Nations family, was organized in 1957 to develop the use of nuclear energy and to ensure that it not be used for military purposes. On December 1, 1976, 109 states were members.

The Agency is governed by the General Conference, consisting of representatives of all member states which convenes each year to debate the Agency's policies and programs. The General Conference also elects members to the 34-member Board of Governors, approves the appointment of the Director General (who serves one or more 4-yr terms) and admits new member states.

The executive body of the Agency is the Board of Governors, which meets four or five times a year. The detailed work of the Agency is conducted by the Secretariat, which in 1975 had a staff of approximately 380 professional members drawn from the technical communities of the member countries.

Major IAEA programs in which the United States participates are:

- Safeguards Accountability of Nuclear Material

- Regional Fuel Cycle Center Study

- Nuclear Safety and Standards

- Scientific Information Exchange

- Technical Assistance Program.

IAEA's major goals in nuclear safety and environmental protection are to ensure the safe operation of nuclear installations and the protection of man and his environment from the harmful effects of nuclear radiation and radioactive or nonradioactive releases from nuclear installations. An important segment of the work is concerned with radioactive waste management. These activities are managed by the Nuclear Safety and Environmental Protection Division of the Department of Technical Operations. 
In the waste management area, the IAEA provides a multinational focus for investigation and development in problem areas which ultimately may be handled satisfactorily only through international solutions. The IAEA's waste mangement activities include:

- Development of mutually agreed upon safety standards and criteria for the management and disposal of radioactive waste arising from all stages of the nuclear fuel cycle. The general approach is to convene an "advisory group" of expert consultants who draft a code of practice. A "review committee" that represents as much as possible the nations with a developed capability in that particular area then revises the draft document into a form that, implicitly, represents a broad consensus. Some codes may either be published at this stage or proceed through further review processes. Finally, the code is brought before the Board of Governors for approval, after which the Director General promulgates the code to member states with the recommendation that it be considered when formulating the countries' own codes in that area of technology.

- Promotion of information exchanges in the radioactive waste management area through international conferences and symposia, technical committees and advisory groups for selected areas of technology, and specialized training courses and seminars. of particular note is the IAEA's Technical Committee on High-Level and Alpha-Bearing Wastes which was first convened in March 1974 and which held its fifth meeting in October 1979. At each meeting, high-level and alpha-bearing waste management activities of the countries represented are reviewed, and discussions are held concerning future directions of the IAEA in this area.

- Coordination of research programs in specific technical areas.

- Issuance of publications in the field of waste management, including the annual "Waste Management Research Abstracts." 
Limited IAEA funds (generally $\$ 150,000$ to $\$ 200,000$ annually) are provided for research and development in selected areas of radioactive waste management and environmental assessment, usually for coordinated research programs involving participating member states.

\section{COMMISSION OF EUROPEAN COMMUNITIES (CEC)}

MEMBER COUNTRIES

$\begin{array}{lll}\text { Belgium(a) } & \text { Federal Republic of Germany(a) } & \text { Luxembourg(a) } \\ \text { Denmark } & \text { Ireland } & \text { Netherlands(a) } \\ \text { France (a) } & \text { Italy(a) } & \text { United Kingdom }\end{array}$

The European Coal and Steel Community (ECSC) was created in 1951 to pool the coal and steel production of the six member states. In 1957, the European Economic Communities (EEC) and the European Atomic Energy Community (Euratom) were formed by the same six member states. In 1967, Euratom was merged into the EEC and its former activities are now under the CEC, which formulates and implements policy for the Community.

Euratom objectives were to develop nuclear research capability, establish nuclear safety standards, encourage the development of nuclear power and exchange information and capital for nuclear enterprises among the member states. The provisions of the original treaty are still in effect, and Euratom objectives for the cooperative development of nuclear energy motivate a major CEC program.

By means of a tax levied on the member states, the CEC acquires funds to support a variety of programs. In the waste management area, the CEC sponsors two types of R\&D programs: the "direct action" fully funded by the CEC and conducted at one of the Commission's Joint Research Centers (primarily JRCIspra in Italy and the European Transuranium Institute at Karlsruhe); and "indirect action" carried out at the research establishments of the member states with partial (up to $50 \%$ ) support from the CEC.

(a) Original members. 
Indirect active waste management programs are planned, approved and budgeted on a five-year cycle; the second such program started in January 1980. Activities in the second indirect action program plan include studies of engineered water- and air-cooled storage of solidified HLW; volume reduction and treatment of TRU wastes; treatment, immobilization and disposal of low- and intermediate-level wastes; handling of process off-gas streams and airborne nuclides; volume reduction and immobilization of cladding hulls; characterization of waste forms; and geologic isolation (a major CEC activity). CEC's share of the cost is approximately 50 million European Units of Account (EUA) ${ }^{(a)}$ about $\$ 60$ million U.S., which amounts to about $50 \%$ of the total cost of the program.

In June 1978, the CEC announced a five-year, \$14M program to develop decommissioning technology. The program is to include studies of long-term integrity of buildings and systems, decontamination for decomissioning purposes, dismantling techniques, methods for processing waste materials such as steel or concrete, large containers for waste transport, quantities of waste produced by decomissioning retired facilities and the influence of facility design on decommissioning.

The CEC direct action R\&D programs at Ispra and Karlsruhe are described in the following sections.

JOINT RESEARCH CENTRE-ISPRA ${ }^{(b)}$

JRC-Ispra is a multidisciplinary nuclear research center with one test reactor, electronic computers, 40 laboratories and various test facilities. The center conducts programs in reactor and nuclear plant safety, treatment and storage of radioactive wastes, hydrogen production by chemical cycles, solar energy, environment and resources, standards and reference substances.

(a) One EUA currentiy equals about $\$ 1.35$.

(b) Ispra is in northern Italy on the eastern shore of Lake Maggiore, about 25 $\mathrm{km}$ from Varese. 
The Ispra Center was set up in 1959 by the Italian government to support Italy's nuclear effort. In 1960, the establishment was transferred to Euratom and is currently operated by CEC as a multinational laboratory.

of the 2300 total staff, approximately 1000 are professionals. The waste management research and development staff has about 60 professionals.

JRC-Ispra programs operate on a four-year budget cycle. The current cycle, which runs from 1980-1983, places emphas is in the nuclear waste management field on risk analys is for geologic repositories and on evaluating actinide transmutation as a TRU disposal technique.

\section{EUROPEAN TRANSURANIUM INSTITUTE}

The European Transuranium Institute, located at the KfK site near Karlsruhe is controlled and supported by CEC. The institute has extensive laboratory facilities fully equipped for handling highly radioactive substances. Programs include basic research on transuranic elements, especially plutonium, and research into their industrial uses.

\section{NUCLEAR ENERGY AGENCY (NEA) (ORGANIZATION FOR ECONOMIC COOPERATION AND DEVELOPMENT)}

The Organization for Economic Cooperation and Development (OECD) was formed in 1948 as the Organization for European Economic Cooperation. It was expanded in 1960 and renamed the OECD. The OECD membership consists chiefly of those developed countries that base their economic structures on the private enterpr ise system. OECD objectives are to:

- promote economic growth of member countries

- provide assistance to less developed countries

- promote worldwide trade expansion.

The OECD's interests in energy are handled by the Nuclear Energy Agency (NEA) and the International Energy Agency (IEA). 
MEMBER COUNTRIES

$\begin{array}{llll}\text { Australia } & \text { France } & \text { Japan } & \text { Sweden } \\ \text { Austria } & \text { Germany (FRG) } & \text { Luxembourg } & \text { Switzerland } \\ \text { Belgium } & \text { Greece } & \text { Netherlands } & \text { Turkey } \\ \text { Canada } & \text { Iceland } & \text { Norway } & \text { United Kingdom } \\ \text { Denmark } & \text { Ireland } & \text { Portugal } & \text { United States } \\ \text { Finland } & \text { Italy } & \text { Spain } & \end{array}$

(New Zealand and Yugoslavia cooperate in certain projects)

The NEA is a specialized agency of the OECD, initially set up in 1958 as the European Nuclear Energy Agency (ENEA). As non-European nations joined OECD, the word "European" was dropped from the name of the Agency.

The main purpose of the Agency is to promote international cooperation among the OECD countries for the development and application of nuclear power for peaceful purposes through international research and development projects and exchange of scientific and technical experience and information. NEA is concerned with reactor research, the nuclear fuel cycle, radioactive waste management, other uses of atomic energy, regulatory aspects and the compilation of nuclear data.

The work program of the Agency is divided between two main sectors. One is concerned with questions regarding the safety and regulation of nuclear activities for which the Nuclear Safety Division, the Radiation Protection and Waste Management Division, and the Legal Affairs Section are responsible. The other sector covers the scientific and economic aspects of nuclear energy, for which the Nuclear Development Division, the Nuclear Science Division, and the NEA Data Bank have been established.

At the request of the $O E C D$, building upon previous efforts of the IEA Working Group on Radioactive Waste Management, the NEA has established committees and working groups and has sponsored seminars concerned with various radioactive waste management problem areas. Major committees include:

- The Radioactive Waste Management Committee (RWMC) of the NEA. Its purpose is to initiate, encourage and coordinate R\&D activities in the field of radioactive waste management, particularly within NEA member states. 
- The NEA Coordinating Group on Geologic Disposal. This group was set up in 1975 to organize the exchange of information between OECD countries, establish a detailed program and time schedule of investigations based on national contributions, identify the areas requiring additional work and make proposals when joint studies are desirable.

- NEA Ad Hoc Study Group. This group has been concerned with legal, financial and administrative problems associated with the waste management situations in member countries.

- Committee on Radiation Protection and Public Health (CRPPH).

\section{EUROCHEMIC (EUROPEAN COMPANY FOR THE CHEMICAL PROCESSING OF IRRADIATED FUELS) (a)}

Eurochemic was organized in 1957 by 13 OECD countries: Austria, Belgium, Denmark, France, Federal Republic of Germany, Italy, Netherlands, Norway, Portugal, Spain, Sweden, Switzerland and Turkey. The company was established to provide European countries with technical know-how in fuel reprocessing through building and operating the Eurochemic Demonstration Reprocessing Plant and an associated research laboratory specializing in aqueous reprocessing of spent nuclear fuels.

The plant was operated from 1966 to 1974, at which time it was shut down and the attention of Eurochemic personnel focused on the management of the reprocessing wastes and decontaminating the reception/storage and reprocessing facilities.

Eurochemic has put much effort into developing the LOTES calcination process for HLW from their fuel reprocessing plant and a technique to embed waste calcine granules or waste glass beads in low-melting alloys. Development of the PAMELA process to produce beads and incorporate them in a metal matrix producing "Vitromet" was a joint effort between Eurochemic and Gelsenberg, a

(a) Eurochemic is located at Mol, Belgium about $100 \mathrm{~km}$ northeast of Brussels (Bruxelles). 
German company. Work on LOTES has been dropped, and Eurochemic is preparing to install an AVM plant, while a German company, DWK (the German fuel cycle company), is preparing to demonstrate the PAMELA process in a pilot plant at Mol.

\section{COUNCIL FOR MUTUAL ECONOMIC ASSISTANCE (CMEA)}

MEMBER COUNTR IES

$\begin{array}{ll}\text { Bulgaria } & \text { Mongolia } \\ \text { Cuba } & \text { Poland } \\ \text { Czechos lovakia } & \text { Rumania } \\ \text { East Germany } & \text { U.S.S.R. } \\ \text { Hungary } & \text { Yugoslavia(a) }\end{array}$

The Council for Mutual Economic Assistance (CMEA), the counterpart of OECD for countries with centrally-controlled economies, has a Standing Commission on the Use of Atomic Energy for Peaceful Purposes. The Commission holds meetings that examine research advances and define areas for additional cooperative endeavors for national experts in radioactive waste management technology.

In 1971, CMEA set up a Coordinating Scientific and Technical Council (CSTC) which is mainly concerned with radioactive waste management and decontamination of equipment. It meets twice a year, the main tasks being promotion of multilateral cooperation, analys is of the status and trends of development in radioactive waste management technology, recommendations for the main direction of R\&D, examination of the economic efficiency of putting technology into practice and organization of the exchange of experience and information. The CSTC has set a high priority on the development of safe disposal methods for radioactive wastes, especially in geologic formations. The environmental aspects of radioactive waste management are covered by a CSTC committee on radiation protection.

(a) Special status country. 
Nuclear power plants currently planned for all CMEA countries except Romania are to use LWRs of Soviet design. Romania is interested in installing the CANDU (PHWR) system to avoid dependence on Soviet enrichment services. It is also reported that a Soviet PWR is to be constructed in Cuba. The CMEA countries, particularly the U.S.S.R., are also emphasizing development of breeder reactors and fusion.

The East European nations and Yugoslavia have cooperation agreements with the Soviet Union on the construction of equipment for nuclear power plants in CMEA countries. Hungary produces gear for water treatment, electronic equipment and heat exchanges; Czechoslovakia produces pressure vessels for reactor units; East Germany produces transportation equipment; Bulgaria produces biological protection devices; Poland produces special valves and fittings; and Yugoslavia produces swing cranes.

\section{FUEL CYCLE}

Fuel cycle manufacturing capability in the CMEA countries is confined mainly to the Soviet Union, which has uranium enrichment facilities and is reportedly building a spent fuel reprocessing plant so that plutonium can be recovered for recycle and use in breeder fuels.

Under a joint R\&D program, the CMEA nations are developing and testing solvent extraction and fluoride volatility processes and equipment for fuel reprocessing. Member states are also working on improved transportation and waste management technology. The CMEA-sponsored waste management R\&D program for 1976-1980 includes the following major activities:

- Treatment of liquid non-high-level wastes

- Perfection of methods for treatment, solidification and storage of radioactive waste, including high-level waste (bituminization and vitrification studies are included)

- Burial of radioactive waste in geologic formations

- Research on techniques for removing radioactive aerosols and gases from materials released to the atmosphere. 


\section{UNITED REPROCESSORS GMbH}

In 1971 the Federal Republic of Germany, United Kingdom and France formed United Reprocessors GmbH to pool their knowledge and experience in the area of spent fuel reprocessing. The three partners are British Nuclear Fuels Limited, Commissariat a l'Énergie Atomique and KEWA Kernbrennstoff Wiederverarbeitung-Gesellschaft mbH.

\section{NUCLEAR TRANSPORT LIMITED (NTL)}

Nuclear Transport Limited (NTL) is a wholly owned subsidiary of British Nuclear Fuels Limited (BNFL), Transnucléaire (TN-France) and Transnuklear (TN-FRG). NTL is the capital investment arm which buys casks, railcars and other capital equipment. They also contract for the task of transporting spent fuel, but subcontract the actual operations to BNFL and TN. The major development effort, through TN, is in shipping/disposal casks for spent fuel. 

PNL -3333

UC -70

\section{DISTRIBUTION}

No. of

Copies

OFFSITE

2 Brookhaven National Laboratory

Reference Section

Research Library

Upton, NY 11973

Brookhaven National Laboratory

Associated Universities, Inc.

Upton, NY 11973

Attn: G. H. Vineyard, Director

Brookhaven National Laboratory

Physics Department

Upton, NY 11973

Attn: P. W. Levy

Engineering Research and

Development Authority

Empire State Plaza

Albany, NY 12223

Attn: J. L. Larocca, Chairman

State University of New York

Department of Physics

Cort 1 and, NY 13045

Attn: R. Chaturved $i$

Nuclear Fuel Services, Inc.

P.0. Box 124

West Valley, NY 14171

Attn: J. P. Duckworth, Plant Manager

Deputy Director for Fuels and Materials

NRC Directorate of Licensing for

Fuels and Materials

4915 St. E lmo Avenue

Bethes da, MD 20014
No. of

Copies

Committee on Radioactive Waste Management

National Academy of Sciences

2101 Constitution Avenue, N.W. Washington, DC 20418

Attn: Dr. John Pomeroy

2 Technology Assessment Division Environmental Protection Agency Washington, DC 20460

Attn: Dave Smith

Technology Assessment Division Environmental Protection Agency Washington, DC 20460

Attn: William Holcomb, Mail Code ANR-459

Nuclear Technology Section

Bureau of Oceanic, International

\& Environmental Science Affairs

Department of State

Washington, DC 20520

Attn: Dixon Hoyle

M/IAEA Vienna

U.S. Department of State

Washington, DC 20520

Attn: Counselor for Atomic

Energy Affairs

DOE Representative to American Embassy (Paris)

APO NY 09777

Attn: James Ammons

Battelle Memorial Institute

505 King Avenue

Columbus, $\mathrm{OH} 43201$

Attn: Beverly Rawls 
No. of

Copies

U.S. Mission, OECD

Department of State

Washington, DC 20521

Attn: Don Booher

U.S. Department of Energy

Tokyo Office - American Embassy

c/o Department of State

Washington, DC 20521

Attn: Billy Hill

U.S. Department of Energy

Brussels Office - USEC

c/o U.S. European Communities

Mission

Department of State

Washington, DC 20521

Attn: Robert Purple

U.S. Department of Energy

Bonn Office - American Embassy

c/o Department of State

Washington, DC 20521

Attn: Raymond $E$. Vener

2 NEW, B-107, HQ

U.S. Department of Energy

Washington, DC 20545

Attn: A. F. Perge

Energy Technology

U.S. Department of Energy

Washington, DC 20545

Attn: J. M. Deutch

NEW, MS B-107

U.S. Department of Energy

Washington, DC 20545

Attn: J. A. Leary

ECT Division

U.S. Department of Energy

Washington, DC 20545

Attn: R. W. Ramsey
No. of

Copies

\author{
AIA Division \\ Forestal MS 7F031 \\ U.S. Department of Energy \\ Washington, DC 20585 \\ Attn: H. Jaffe
}

AIA Division

Forestal MS 7F031

U.S. Department of Energy

Washington, DC 20585

Attn: M. D. McDonough

Nuclear Power Development Division NPD, B-107, HQ

U.S. Department of Energy

Washington, DC 20545

Attn: W. Ballard

NEW, B-107, HQ

U.S. Department of Energy

Washington, DC 20545

Attn: C. R. Cooley

Division of Biomedical and Environmental Research

Earth Sciences Branch

U.S. Department of Energy

Washington, DC 20545

Attn: W. G. Belter

Division of Environmental

Control Technology

U.S. Department of Energy

Washington, DC 20545

Attn: W. E. Mott

Division of Transportation and Fuel Storage

NEW, B-107

U.S. Department of Energy

Washington, DC 20545

Attn: M. J. Lawrence

Division of Transportation and Fuel Storage

NEW, B-107

U.S. Department of Energy

Washington, DC 20545

Attn: R. B. Chitwood 
No. of

Copies

Division of Waste Management

U.S. Department of Energy

Washington, DC 20545

Attn: C. H. George

Division of Waste Products

NEW, B-107

U.S. Department of Energy

Washington, DC 20545

Attn: C. A. Heath

Division of Waste Products

NEW, B-107, HQ

U.S. Department of Energy

Washington, DC 20545

Attn: G. Oerte 1

Division of Waste Management

U.S. Department of Energy

Washington, DC 20545

Attn: J. M. Taub

Division of Waste Isolation

NEW, B-107, HQ

U.S. Department of Energy

Washington, DC 20545

Attn: D. L. Vieth

Division of Waste Management

U.S. Department of Energy

Washington, DC 20545

Attn: R. D. Walton

2 U.S. Nuclear Regulatory Commission MS 687-SS

Washington, DC 20555

Attn: John Martin, Division of Waste Management

U.S. Nuclear Regulatory Commission MS 687-SS

Washington, DC 20555

Attn: David M. Rohrer

U.S. Nuclear Regulatory Commission Washington, DC 20555

Attn: Margaret Conyngham, Reference Libraries
No. of

Copies

Director

Savannah River Laboratory

Aiken, SC 29801

Savannah River Laboratory

Aiken, SC 29801

Attn: Leon Meyer

2 Spent Fuels Project

Savannah River Operations Office

P.0. Box A

Aiken, SC 29801

Attn: E. Wingate

Savannah River Operations Office

U.S. Department of Energy

P.0. Box A

Aiken, SC 29801

Attn: N. Stetson, Manager

Du Pont Company, Aiken (DOE)

E.I. Du Pont de Nemours \& Co.

Savannah River Laboratory

Aiken, SC 29801

Attn: M. D. Boersma

Du Pont Company, Aiken (DOE)

E.I. Du Pont de Nemours \& Co.

Savannah River Laboratory

Aiken, SC 29801

Attn: A. S. Jennings

Du Pont Company, Aiken (DOE)

E.I. Du Pont de Nemours \& Co.

Savannah River Laboratory

Aiken, SC 29801

Attn: P. H. Permar

Allied-General Nuclear Services

P.0. Box 847

Barnwe 11, SC 29812

Attn: J. A. Buckham

Allied-General Nuclear Services

P.0. Box 847

Barnwe 11, SC 29812

Attn: A. Williams 
No. of

Copies

Orkand Corporation

8630 Fenton Street, Suite 938

Silver Spring, MD 01612

Attn: James McIntyre

Oak Ridge Operations Office

U.S. Department of Energy

P.0. Box E

Oak Ridge, TN 37830

Attn: R. J. Hart, Manager

Oak Ridge National Laboratory

P.0. Box $X$

Oak Ridge, TN 37830

Attn: D. B. Trauger, Associate Director

2 Reference Section, Central

Research Library

Room 175-B, B1dg. 4500N

Union Carbide Corporation

Oak Ridge National Laboratory

P.0. Box $X$

Oak Ridge, TN 37830

Union Carbide Corporation

Oak Ridge National Laboratory

P.0. Box X

Oak Ridge, TN 37830

Attn: Ray E. Blanco

Union Carbide Corporation

Oak Ridge National Laboratory

P.0. Box X

Oak Ridge, TN 37830

Attn: R. S. Lowrie

Union Carbide Corporation

Oak Ridge National Laboratory

P.0. Box $Y$

Oak Ridge, TN 37830

Attn: W. C. McClain

Oak Ridge National Laboratory

P.0. Box X

Oak Ridge, TN 37830

Attn: John E. Van Cleve, Jr., Bldg. 7601
No. of

Copies

Oak Ridge National Laboratory

P.0. Box $X$

Oak Ridge, TN 37830

Attn: Cathy Fore,

Bldg. 2028

27 DOE Technical Information Center

Union Carbide Corporation

Oak Ridge National Laboratory

P.0. Box Y

Oak Ridge, TN 37830

Attn: J. 0. Blomeke

2 Union Carbide Corporation

Oak Ridge National Laboratory

P.0. Box $Y$

Oak Ridge, TN 37830

Attn: D. E. Ferguson

Battelle Memorial Institute

505 King Avenue

Columbus, $\mathrm{OH} 43201$

Battelle Memorial Institute

505 King Avenue

Columbus, $\mathrm{OH} 43201$

Attn: J. M. Batch

Battelle Memorial Institute

505 King Avenue

Columbus, $\mathrm{OH} \quad 43201$

Attn: H. C. Burkholder

Battelle Memorial Institute

$505 \mathrm{King}$ Avenue

Columbus, $\mathrm{OH} \quad 43201$

Attn: Ron Hall

Monsanto Research Facility

Mound Laboratory

P.0. Box 32

Miamisburg, $\mathrm{OH} 45342$

Attn: J. R. McClain, Director 
No. of

Copies

Monsanto Research Facility

Mound Laboratory

P.0. Box 32

Miamisburg, $\mathrm{OH} 45342$

Attn: C. F. Kershner

Chicago Operations Office

U.S. Department of Energy

9800 South Cass Avenue

Argonne, IL 60439

Attn: R. H. Bauer, Manager

Chicago Patent Group

U.S. Department of Energy

9800 South Cass Avenue

Argonne, IL 60439

Attn: A. A. Churm

Argonne National Laboratory

9700 South Cass Avenue

Argonne, IL 60439

Attn: J. Howard Kittel

Argonne National Laboratory 9700 South Cass Avenue

Argonne, IL 60439

Attn: L. Burris

Argonne National Laboratory

9700 South Cass Avenue

Argonne, IL 60439

Attn: M. J. Ste indler

Rockly Flats Area Office

U.S. Department of Energy

Golden, CO 80401

Attn: Don Ofte, Manager

Atomics International Division

Rockwe 11 Internatina 1

Rocky Flats Plant

P.0. Box 464

Golden, CO 80401

Attn: R. 0. Wi 11 iams, General

Manager
No. of

Copies

2 Rockwe 11 International

Rocky Flats Plant

Golden, CO 80401

Attn: M. A. Thompson

Idaho Operations Office

U.S. Department of Energy

550 2nd Street

Idaho Falls, ID 83401

Attn: C. E. Williams, Manager

Exxon Nuclear Idaho Company, Inc. 1955 Fremont

P.0. Box 2800

Idaho Falls, ID 83401

Attn: R. W. McCollugh

Exxon Nuclear Idaho Company, Inc. 1955 Fremont

P.0. Box 2800

Idaho Falls, ID 83401

Attn: T. R. Thomas

Exxon Nuclear Idaho Company, Inc. 1955 Fremont

P.0. Box 2800

Idaho Falls, ID 83401

Attn: A. P. Roeh, Manager

Exxon Nuclear Idaho Company, Inc. 1955 Fremont

P.0. Box 2800

Idaho Fal1s, ID 83401

Attn: R. A. Brown

Exxon Nuclear Idaho Company, Inc. 1955 Fremont

P.0. Box 2800

Idaho Falls, ID 83401

Attn: C. A. Hawley

Exxon Nuclear Idaho Company, Inc. 1955 Fremont

P.0. Box 2800

Idaho Falls, ID 83401

Attn: D. A. Knecht 
No. of

Copies

Exxon Nuclear Idaho Company, Inc.

(File Copy)

1955 Fremont

P.0. Box 2800

Idaho Falls, ID 83401

EG\&G Idaho, Inc.

P.0. Box 1625

Idaho Falls, ID 83401

Attn: R. W. Kiehn, Manager

College of Engineering

University of Arizona

Tucson, $A Z 85721$

Attn: R. G. Post

Albuquerque Operations Office U.S. Department of Energy

P.0. Box 5400

Albuquerque, NM 87115

Attn: R. Y. Lowrey

Albuquerque Operations Office U.S. Department of Energy

P.0. Box 5400

Albuquerque, NM 87115

Attn: A. L. Taboas

Sand ia Laboratories

P.0. Box 5800

Albuquerque, NM 87185

Attn: D. R. Anderson

Sandia Laboratories

P.0. Box 5800

Albuquerque, NM 87185

Attn: W. D. Weart

Sandia Laboratories

P.0. Box 5800

Albuquerque, NM 87185

Attn: R. W. Lynch

Sand ia Laboratories

P.0. Box 5800

Albuquerque, NM 87185

Attn: R. M. Jefferson
No. of

Copies

Sandia Laboratories

P.0. Box 5800

Albuquerque, NM 87185

Attn: H. D. Sivinski,

Div. 4535

Sandia Laboratories

P.0. Box 5800

Albuquerque, NM 87185

Attn: Morgan Sparks, President

Sand ia Laboratories

P.0. Box 5800

Albuquerque, NM 87185

Attn: Jerry Freedman

Div. 4551

Sandia Laboratories

P.0. Box 5800

Albuquerque, NM 87185

Attn: Robert E. Luna

Org. 4551

Technical Library

Sandia Laboratories

P.0. Box 5800

Albuquerque, NM 87185

Attn: Jane Lord

WIPP Project Office

P.0. Box 5400

Albuquerque, NM 87185

Attn: D. T. Schueler

University of New Mexico

Albuquerque, NM 87131

Attn: S. E. Logan

Los Alamos Area Office

U.S. Department of Energy

Los Alamos, NM 87544

Attn: K. R. Braziel, Manager

Director

LoS Alamos Scientific Laboratory

Los Alamos, NM 87544 
No. of

Copies

Group Leader, Waste Management University of Cal if ornia LASL

Los Alamos, NM 87544

Attn: T. K. Keenan

Nevada Operations Office

U.S. Department of Energy

P.0. Box 14100

Las Vegas, NV 89114

Attn: M. E. Gates, Manager

Gulf Energy and Environmental Systems

P.0. Box 81608

San Diego, CA 92138

Attn: L. H. Brooks

Electric Power Research Institute P.0. Box 10412

Palo Alto, CA 94304

Attn: R. F. Williams

Electric Power Research Institute P.0. Box 10412

Palo Alto, CA 94304

Attn: L. Henning

Lawrence Livermore Laboratory

P.0. Box 808

Livermore, CA 94550

Attn: R. E. Batzel, Director

Sandia Laboratories

Livermore, CA 94550

Attn: T. B. Cook, Jr., Vice President

San Francisco Operations Office

U.S. Department of Energy

1333 Broadway, Wells Fargo Bldg. Oakland, CA 94612

Attn: L. Lanni, Nuclear Energy Division

Lawrence Berkeley Laboratory

University of California

Berkeley, CA 94720

Attn: A. M. Sessler, Director
No. of

Copies

Lawrence Berkeley Laboratory

University of California

Berkeley, CA 94720

Attn: Lew is Cohen

General Electric Company

175 Curtner Avenue

(M/C 160)

San Jose, CA 95125

Attn: R. G. Barnes

U.S. Department of Interior

Bureau of Mines

Albany Research Center

1450 W. Queen Avenue

Albany, OR 97321

Attn: R. A. Beall

Human Affairs Research Centers

4000 N.E. 41st Street

Seattle, WA 98105

Attn: C. R. Schuller

Kenneth J. Schneider

M/IAEA Vienna

U.S. Department of State

Washington, DC 20520

\section{FORE IG N}

International Atomic Energy Agency

Division of Nuclear Safety and

Environmental Protection

Wagramerstrasse 5, P.0. Box 100

A-1400 Vienna

AUSTRIA

Attn: Everett R. Irish, Waste

Management Section

EMSCo.

Spechtlaan 8

130 Brasschaat

BELG IUM

Attn: E. M. Shank 
No. of

Copies

Fred Karlsson

SKBF /KBS

Box 5864

S-102 48

Stockholm, Sweden

ONSITE

6 DOE Richland Operations Office

P. A. Craig

0. J. Elgert

A. G. Fremling

B. J. Melton

H. E. Ransom

M. Shupe

1 Exxon

S. J. Beard

1 Joint Center for Graduate Study

J. Cooper

10 Rockwell Hanford Operations

H. Babad

D. J. Cockeram

R. A. Deju

R. J. Gimara

E. J. Kosiancic

C. M. Manry

J. H. Roecker

M. J. Smith

D. D. Wodrich

File Copy

2 United Nuclear Industries, Inc.

T. E. Dabrowsk i

A. E. Engler
No. of

Copies

3 Westinghouse Hanford Company

J. B. Yasinsky

A. G. Blasewitz

E. A. Evans

73 Pacific Northwest Laboratory

D. E. Olesen

W. F. Bonner

A. Brandstetter

L. L. Burger

D. B. Cearlock

T. D. Chikalla

J. M. Davidson

R. L. Dillon

J. W. Finnigan

J. J. Fuquay

K. M. Harmon (20) $27 \%$ A

A. J. Haverfield

K. A. Hsieh

E. R. Irish

J. H. Jarrett

J. A. Kelman (20)

M. R. Kreiter

L. T. Lakey

R. P. Marshall

J. L. McE Iroy

R. E. Night ingale

D. E. Olesen

A. M. Platt

J. V. Robinson

L. A. Stout

C. M. Unruh

H. H. Van Tuyl

L. D. Williams

Technical Information (5)

Publishing Coordination $\mathrm{CO}(2)$

1 UNC Nuclear Industries

G. F. Jones 